\title{
Organosoluble Copper Clusters as Precatalysts for Carbon-Heteroelement Bond Forming Reactions: Microwave and Conventional Heating
}

Gerald F. Manbeck, Adam J. Lipman, Robert A. Stockland Jr., ${ }^{*}$ Adrienne L. Freidl, Amy F. Hasler, Joshua J. Stone, and Ilia A. Guzei ${ }^{\dagger}$

Department of Chemistry, Bucknell University, Lewisburg, PA 17837

General Considerations:

Synthesis of known alkyl aryl ethers

$\mathrm{S} 2-\mathrm{S} 21$

${ }^{1} \mathrm{H},{ }^{13} \mathrm{C}, \mathrm{COSY}$, and DEPT - 135 NMR spectra

S22-S29

CAS numbers and references to known compounds

$\mathrm{S} 30-\mathrm{S} 31$

Crystallographic data section

S32-S41 


\section{Experimental}

General considerations: The synthesis of the copper clusters was carried out under nitrogen using standard Schlenk techniques. Coupling reactions were carried out under an atmosphere of nitrogen or air. The alcohols were dried by distillation from $\mathrm{Mg}$ turnings unless specified otherwise. The $\mathrm{K}\left[\mathrm{S}_{2} \mathrm{P}(\mathrm{OR})_{2}\right]$ salts used in this study were prepared by treatment of $\mathrm{P}_{4} \mathrm{~S}_{10}$ with the appropriate alcohol followed by addition of 1 equiv of $\mathrm{KOH} .{ }^{1}$ All yields are based upon isolated material with greater than $95 \%$ purity as determined by ${ }^{1} \mathrm{H}$ NMR spectroscopy and GC unless specified otherwise. Spectroscopic data of known compounds were compared with literature values or authentic samples. ${ }^{1} \mathrm{H},{ }^{13} \mathrm{C}\left\{{ }^{1} \mathrm{H}\right\}$, and ${ }^{31} \mathrm{P}\left\{{ }^{1} \mathrm{H}\right\}$ NMR spectra were recorded at at $25{ }^{\circ} \mathrm{C}$ unless specified otherwise. ${ }^{1} \mathrm{H}$ and ${ }^{13} \mathrm{C}$ chemical shifts were determined by reference to residual ${ }^{1} \mathrm{H}$ and ${ }^{13} \mathrm{C}$ solvent resonances. All coupling constants are given in Hertz. ${ }^{31} \mathrm{P}$ NMR spectra were referenced to external $\mathrm{H}_{3} \mathrm{PO}_{4}(0 \mathrm{ppm})$. Microwave catalyzed reactions were carried out in $10 \mathrm{~mL}$ pressure tubes using a CEM Discover microwave reactor. Title compounds were judged to be $>95 \%$ pure based upon GC chromatographic and NMR spectroscopic analysis.

Multinuclear NMR spectroscopic data and elemental analyses are provided for new compounds. For known compounds, the ${ }^{1} \mathrm{H}$ NMR data is listed for convenience. The connectivity of the compounds was determined by ${ }^{1} \mathrm{H}-{ }^{1} \mathrm{H}$ COSY and ${ }^{1} \mathrm{H}-{ }^{13} \mathrm{C}$ HETCOR experiments.

Preparation of 4-ethoxyltoluene (Table 2, entry 1): Method A. The general procedure was followed using 2 (0.008 g, $4.1 \mu \mathrm{mol})$, 4-iodotoluene (0.20 g, $0.92 \mathrm{mmol}), \mathrm{Cs}_{2} \mathrm{CO}_{3}(0.60 \mathrm{~g}, 1.8$ $\mathrm{mmol})$, and crushed molecular sieves $(0.50 \mathrm{~g})$. The test tube was evacuated and refilled with nitrogen before addition of the ethanol $(1.5 \mathrm{~mL}, 26 \mathrm{mmol})$. The reaction mixture was stirred at 
$110^{\circ} \mathrm{C}$ for 11 hours. After cooling the reaction mixture to room temperature, the volatiles were evaporated under vacuum, and the residue was extracted with hexane and filtered through a short column of silica $(1 \times 1 \mathrm{~cm})$. Removal of the volatiles afforded $0.10 \mathrm{~g}(80 \%)$ of the title compound as colorless oil. ${ }^{1} \mathrm{H} \mathrm{NMR}\left(\mathrm{CDCl}_{3}, 25^{\circ} \mathrm{C}\right): \delta 7.09\left(\mathrm{~d}, 2 \mathrm{H}, \mathrm{J}=8.4,-\mathrm{C}_{6} H_{4} \mathrm{Me}\right), 6.81(\mathrm{~d}, 2 \mathrm{H}, \mathrm{J}=8.4$, $\left.-\mathrm{C}_{6} \mathrm{H}_{4} \mathrm{Me}\right), 4.02\left(\mathrm{q}, 2 \mathrm{H}, \mathrm{J}=7.1,-\mathrm{OCH}_{2}-\right), 2.30\left(\mathrm{~s}, 3 \mathrm{H},-\mathrm{C}_{6} \mathrm{H}_{4} M e\right), 1.41\left(\mathrm{t}, 3 \mathrm{H}, \mathrm{J}=7.0,-\mathrm{CH}_{2} M e\right)$. The above procedure was repeated in the presence of air without deoxygenating the reagents or solvent. Molecular sieves were not used in this reaction. The reaction time was stirred for $36 \mathrm{~h}$, and the title compound was isolated in $71 \%$ yield $(0.088 \mathrm{~g})$ after purification by column chromatography (silica: hexanes/ethyl acetate 30:1).

Preparation of 4-ethoxyltoluene (Table 2, entry 1): Method B. The general procedure was followed using $2(0.008 \mathrm{~g}, 4.1 \mu \mathrm{mol})$, 4-iodotoluene $(0.20 \mathrm{~g}, 0.92 \mathrm{mmol}), \mathrm{Cs}_{2} \mathrm{CO}_{3}(0.60 \mathrm{~g}, 1.84$ mmol), and crushed molecular sieves $(0.5 \mathrm{~g})$. The reactor vial was evacuated and refilled with nitrogen before addition of the ethanol $(1.50 \mathrm{~mL}, 26 \mathrm{mmol})$. The microwave settings were as follows: temperature $=125^{\circ} \mathrm{C}$, maximum microwave power $=50$ watts, maximum pressure $=$ $300 \mathrm{psi}$, and reaction time $=2 \mathrm{~h}$. The maximum power was held until the desired temperature was reached. The magnetron power was decreased to $39 \mathrm{~W}$ (130 psi) in order to maintain the temperature for the remainder of the reaction. The reaction mixture was cooled to room temperature, filtered through a small plug of silica gel, and dried under vacuum with gentle heating. The residue was extracted with hexane and filtered through a short column of silica (1x1 $\mathrm{cm})$. Removal of the volatiles afforded $0.094 \mathrm{~g}(75 \%)$ of the title compound as a colorless oil. The above procedure was repeated in the presence of air without deoxygenating the reagents or solvent. Molecular sieves were not used in this experiment. The microwave power and pressure 
settings were the same as above, and the reaction time was increased to 3 hours. The title compound was isolated in $70 \%$ yield $(0.87 \mathrm{~g})$ after purification by column chromatography (silica hexane/ethyl acetate 30:1).

Preparation of 4-propyoxyltoluene (Table 2, entry 1): Method A. The general method was followed using $2(0.008 \mathrm{~g}, 4.1 \mu \mathrm{mol})$, and 4-iodotoluene $(0.20 \mathrm{~g}, 0.92 \mathrm{mmol}), \mathrm{Cs}_{2} \mathrm{CO}_{3}(0.60 \mathrm{~g}$, $1.8 \mathrm{mmol})$, and molecular sieves $(0.5 \mathrm{~g})$. The flask was evacuated and refilled with nitrogen, and 1-propanol $(1.5 \mathrm{~mL}, 20 \mathrm{mmol})$ was added by syringe. After stirring at $110^{\circ} \mathrm{C}$ for 11 hours, the volatiles were evaporated under vacuum and the residue was filtered through a plug of silica gel eluting with hexane. Evaporation of the hexane afforded $0.12 \mathrm{~g}(87 \%)$ of the title compound as

a colorless oil. ${ }^{1} \mathrm{H}$ and ${ }^{13} \mathrm{C}\left\{{ }^{1} \mathrm{H}\right\}$ NMR spectra are shown after the experimental descriptions. ${ }^{1} \mathrm{H}$ $\operatorname{NMR}\left(\mathrm{CDCl}_{3}, 25^{\circ} \mathrm{C}\right): \delta 7.10\left(\mathrm{~d}, 2 \mathrm{H}, \mathrm{J}=8.3,-\mathrm{C}_{6} H_{4} \mathrm{Me}\right), 6.83\left(\mathrm{~d}, 2 \mathrm{H}, \mathrm{J}=8.4,-\mathrm{C}_{6} H_{4} \mathrm{Me}\right), 3.91(\mathrm{t}$, $\left.2 \mathrm{H}, \mathrm{J}=6.6, \mathrm{OCH}_{2^{-}}\right), 2.30\left(\mathrm{~s}, 3 \mathrm{H}, \mathrm{C}_{6} \mathrm{H}_{4} \mathrm{Me}\right), 1.80\left(\mathrm{~m}, 2 \mathrm{H},-\mathrm{CH}_{2^{-}}\right), 1.05\left(\mathrm{t}, 3 \mathrm{H}, \mathrm{J}=7.4,-\mathrm{CH}_{2} \mathrm{CH}_{3}\right)$. The above procedure was repeated in the presence of air and without deoxygenating the reagents or solvent. Molecular sieves were not used in this reaction. The reaction was stirred at $110{ }^{\circ} \mathrm{C}$ for $36 \mathrm{~h}$, and the title compound was isolated in $80 \%$ yield $(0.11 \mathrm{~g})$ after purification by column chromatography (silica: hexane/ethyl acetate 30:1).

Preparation of 4-propyoxyltoluene (Table 2, entry 1): Method B. The general method was followed using 2 (0.008 g, $4.1 \mu \mathrm{mol})$, 4-iodotoluene (0.20 g, $0.92 \mathrm{mmol})$, molecular sieves (0.5 $\mathrm{g})$, and $\mathrm{Cs}_{2} \mathrm{CO}_{3}(0.60 \mathrm{~g}, 1.84 \mathrm{mmol})$. The flask was evacuated and refilled with nitrogen, and 1propanol (1.5 mL, $20 \mathrm{mmol})$ was added by syringe. The microwave settings were as follows: temperature $=125^{\circ} \mathrm{C}$, maximum microwave power $=50$ watts, maximum pressure $=300 \mathrm{psi}$, and reaction time $=2 \mathrm{~h}$. The maximum power was held until the desired temperature was 
reached. The magnetron power was decreased to $42 \mathrm{~W}$ (52 psi) in order to maintain the temperature for the remainder of the reaction. Intermittent (not constant) cooling was also used to maintain the temperature these experiments. The reaction was cooled to room temperature and the volatiles were removed under vacuum. The residue was extracted with hexane and filtered through a short column of silica gel $(1 \mathrm{x} 1 \mathrm{~cm})$. Removal of the hexane afforded $0.115 \mathrm{~g}$ $(83 \%)$ of the title compound.

The above procedure was repeated in the presence of air and without deoxygenating the reagents or solvent. Molecular sieves were not used in this reaction. The microwave power and pressure settings were the same as above, but the reaction time was increased to 3 hours. The title compound was isolated in $72 \%$ yield $(0.10 \mathrm{~g})$ after purification by column chromatography (silica hexane/ethyl acetate 30:1).

Preparation of 4-hexyloxyanisole (Table 2, entry 2): Method A. The general method was followed using $2(0.008 \mathrm{~g}, 4.1 \mu \mathrm{mol})$, and 4-iodoanisole $(0.20 \mathrm{~g}, 0.85 \mathrm{mmol}), \mathrm{Cs}_{2} \mathrm{CO}_{3}(0.56 \mathrm{~g}$, $1.7 \mathrm{mmol})$, and molecular sieves $(0.5 \mathrm{~g})$. The flask was evacuated and refilled with nitrogen, and hexyl alcohol (1.5 mL, $12 \mathrm{mmol})$ was added by syringe. After stirring at $110{ }^{\circ} \mathrm{C}$ for 11 hours, the reaction mixture was filtered through a short column of silica gel $(1 \mathrm{x} 1 \mathrm{~cm})$ and dried under vacuum with gentle heating. Purification by column chromatography (silica gel: hexane/ethyl acetate 30:1) afforded $0.15 \mathrm{~g}(84 \%)$ of a pale yellow oil. ${ }^{1} \mathrm{H} \mathrm{NMR}\left(\mathrm{CDCl}_{3}, 25^{\circ} \mathrm{C}\right): \delta 6.90(\mathrm{~s}, 4 \mathrm{H}$, $\left.-\mathrm{C}_{6} \mathrm{H}_{5} \mathrm{OMe}\right), 4.02\left(\mathrm{t}, 2 \mathrm{H}, \mathrm{J}=6.6,-\mathrm{OCH}_{2^{-}}\right), 3.88(\mathrm{~s}, 3 \mathrm{H},-\mathrm{OMe}), 1.86\left(\mathrm{~m}, 2 \mathrm{H},-\mathrm{CH}_{2^{-}}\right), 1.47(\mathrm{~m}$, $\left.2 \mathrm{H},-\mathrm{CH}_{2^{-}}\right), 1.35\left(\mathrm{~m}, 4 \mathrm{H},-\mathrm{CH}_{2^{-}}\right) 0.92\left(\mathrm{t}, 3 \mathrm{H}, \mathrm{J}=7.42,-\mathrm{CH}_{3}\right)$. 
The above procedure was repeated in the presence of air without deoxygenating the reagents or solvent. The reaction time was increased to 36 hours, and the title compound was isolated in 82 $\%$ yield $(0.146 \mathrm{~g})$.

Preparation of 4-hexyloxylanisole (Table 2, entry 2): Method B. The general method was followed using $2(0.008 \mathrm{~g}, 4.1 \mu \mathrm{mol})$, 4-iodoanisole $(0.20 \mathrm{~g}, 0.85 \mathrm{mmol})$, and $\mathrm{Cs}_{2} \mathrm{CO}_{3}(0.56 \mathrm{~g}$, $1.7 \mathrm{mmol})$. The flask was evacuated and refilled with nitrogen, and hexyl alcohol (1.5 mL, 12 mmol) was added by syringe. The microwave settings were as follows: temperature $=125^{\circ} \mathrm{C}$, maximum microwave power $=50$ watts, maximum pressure $=300 \mathrm{psi}$, and reaction time $=3 \mathrm{~h}$. The maximum power was held until the desired temperature was reached. The magnetron power was decreased to $35 \mathrm{~W}$ (14 psi) in order to maintain the temperature for the remainder of the reaction. Intermittent (not constant) cooling was also used to maintain the temperature these experiments. The reaction was cooled to room temperature, and dried under vacuum with gentle heating. Purified by column chromatography (silica gel: hexane/ethyl acetate 30:1) afforded $0.155 \mathrm{~g}(87 \%)$ of the title compound as a pale yellow oil.

The above procedure was repeated in the presence of air without deoxygenating the reagents or solvent. Molecular sieves were not used in this experiment. The title compound was isolated in $79 \%$ yield $(0.14 \mathrm{~g})$ using the same microwave settings but increasing the irradiation time to $4 \mathrm{~h}$.

Preparation of 4-propoxylanisole (Table 2, entry 2): Method A. The general method was followed using $2(0.008 \mathrm{~g}, 4.1 \mu \mathrm{mol})$, and 4-iodoanisole $(0.20 \mathrm{~g}, 0.85 \mathrm{mmol}), \mathrm{Cs}_{2} \mathrm{CO}_{3}(0.56 \mathrm{~g}$, $1.7 \mathrm{mmol})$, and molecular sieves $(0.5 \mathrm{~g})$. The flask was evacuated and refilled with nitrogen, and 1-propanol $(1.5 \mathrm{~mL}, 20 \mathrm{mmol})$ was added by syringe. After stirring at $110^{\circ} \mathrm{C}$ for 11 hours, the reaction was filtered through a short column of silica $(1 \times 1 \mathrm{~cm})$ and dried under vacuum with 
gentle heating. Purification by column chromatography (silica gel: hexane/ethyl acetate 10:1) afforded $0.13 \mathrm{~g}(92 \%)$ of a pale yellow oil. ${ }^{1} \mathrm{H} \mathrm{NMR}\left(\mathrm{CDCl}_{3}, 25^{\circ} \mathrm{C}\right): \delta 6.91\left(\mathrm{~s}, 4 \mathrm{H},-\mathrm{C}_{6} \mathrm{H}_{4} \mathrm{OMe}\right)$, $3.99\left(\mathrm{t}, 2 \mathrm{H}, \mathrm{J}=6.6,-\mathrm{OCH}_{2^{-}}\right), 3.88(\mathrm{~s}, 3 \mathrm{H},-\mathrm{OMe}), 1.89\left(\mathrm{~m}, 2 \mathrm{H},-\mathrm{CH}_{2^{-}}\right), 1.06(\mathrm{t}, 3 \mathrm{H}, \mathrm{J}=7.42$, $\left.\mathrm{CH}_{2} \mathrm{Me}\right)$.

The above procedure was repeated in the presence of air without deoxygenating the reagents or solvent. Molecular sieves were not used in this reaction. The reaction time was stirred at $110^{\circ} \mathrm{C}$ for 36 hours, and the title compound was isolated in $85 \%$ yield $(0.12 \mathrm{~g})$.

Preparation of 4-propoxylanisole (Table 2, entry 2): Method B. The general method was followed using 2 (0.008 g, $4.1 \mu \mathrm{mol})$, 4-iodoanisole (0.20 g, $0.85 \mathrm{mmol})$, crushed molecular sieves $(0.5 \mathrm{~g})$, and $\mathrm{Cs}_{2} \mathrm{CO}_{3}(0.56 \mathrm{~g}, 1.7 \mathrm{mmol})$. After the flask was evacuated and refilled with nitrogen, and 1-propanol $(1.5 \mathrm{~mL}, 20 \mathrm{mmol})$ was added by syringe. The microwave settings were as follows: temperature $=125^{\circ} \mathrm{C}$, maximum microwave power $=50$ watts, maximum pressure $=300 \mathrm{psi}$, and irradiation time $=3 \mathrm{~h}$. The maximum power was held until the desired temperature was reached. The magnetron power was decreased to $40 \mathrm{~W}$ (52 psi) in order to maintain the temperature for the remainder of the reaction. Intermittent (not active) cooling was also used to maintain the temperature these experiments. The reaction was cooled to $50{ }^{\circ} \mathrm{C}$, filtered through a short plug of silica gel, and dried under vacuum with gentle heating. Purification by column chromatography (silica: hexanes/ethyl acetate 10:1) afforded $0.11 \mathrm{~g}$ (78 $\%$ ) of the title compound as a pale yellow oil.

The above procedure was repeated in the presence of air without deoxygenating the reagents or solvent. Molecular sieves were not used in this reaction. The irradiation time was increased to 4 hours and the title compound was isolated in $74 \%$ yield $(0.105 \mathrm{~g})$. 
Preparation of 2-hexyloxytoluene (Table 2, entry 3): Method A. The general method was followed using $2(0.008 \mathrm{~g}, 4.1 \mu \mathrm{mol})$, 2-iodotoluene $(0.11 \mathrm{~mL}, 0.86 \mathrm{mmol})$, crushed molecular sieves $(0.5 \mathrm{~g})$ and $\mathrm{Cs}_{2} \mathrm{CO}_{3}(0.56 \mathrm{~g}, 1.7 \mathrm{mmol})$. The flask was evacuated and refilled with nitrogen, and hexyl alcohol $(1.5 \mathrm{~mL}, 12 \mathrm{mmol})$ was injected by syringe. After stirring at $110^{\circ} \mathrm{C}$ for 24 hours, the volatiles were evaporated under vacuum, and the residue was extracted with hexane and filtered through a plug of silica gel eluting with hexane. Evaporation of the hexane under vacuum afforded $0.14 \mathrm{~g}(84 \%)$ of the title compound as a colorless oil. ${ }^{1} \mathrm{H} \mathrm{NMR}\left(\mathrm{CDCl}_{3}\right.$, $\left.25^{\circ} \mathrm{C}\right): \delta 7.18\left(\mathrm{~m}, 2 \mathrm{H},-\mathrm{C}_{6} H_{4} \mathrm{Me}\right), 6.86\left(\mathrm{~m}, 2 \mathrm{H},-\mathrm{C}_{6} H_{4} \mathrm{Me}\right), 3.99\left(\mathrm{t}, 2 \mathrm{H}, \mathrm{J}=6.5,-\mathrm{OCH}_{2^{-}}\right), 1.84(\mathrm{~m}$, 2H, $\left.-\mathrm{CH}_{2^{-}}\right), 1.52\left(\mathrm{~m}, 2 \mathrm{H},-\mathrm{CH}_{2^{-}}\right), 1.39\left(\mathrm{~m}, 4 \mathrm{H},-\mathrm{CH}_{2^{-}}\right), 0.95\left(\mathrm{t}, 3 \mathrm{H}, \mathrm{J}=7.0,-\mathrm{CH}_{2} \mathrm{Me}\right)$.

The above procedure was repeated in the presence of air without deoxygenating the reagents or solvent. Molecular sieves were not used in this reaction. The reaction was stirred at $110{ }^{\circ} \mathrm{C}$ for $48 \mathrm{~h}$, and the title compound was isolated in $78 \%$ yield $(0.13 \mathrm{~g})$ after purification by column chromatography (silica: hexane).

Preparation of 2-hexyloxyltoluene (Table 2, entry 3): Method B. The general method was followed using $2(0.008 \mathrm{~g}, 4.1 \mu \mathrm{mol})$, 2-iodotoluene $(0.11 \mathrm{~mL}, 0.86 \mathrm{mmol})$, molecular sieves $(0.5$ $\mathrm{g})$, and $\mathrm{Cs}_{2} \mathrm{CO}_{3}(0.56 \mathrm{~g}, 1.7 \mathrm{mmol})$. The flask was evacuated and refilled with nitrogen, and hexyl alcohol (1.5 mL, $12 \mathrm{mmol})$ was added by syringe. The microwave settings were as follows: temperature $=125^{\circ} \mathrm{C}$, maximum microwave power $=50$ watts, maximum pressure $=$ $300 \mathrm{psi}$, and reaction time $=5 \mathrm{~h}$. The maximum power was held until the desired temperature was reached. The magnetron power was decreased to $39 \mathrm{~W}$ (14 psi) in order to maintain the temperature for the remainder of the reaction. Intermittent (not constant) cooling was also used to maintain the temperature these experiments. After the reaction was cooled to room 
temperature, the volatiles were removed under vacuum, and the reaction mixture was extracted with hexane and filtered through a plug of silica gel eluting with hexane. Evaporation of the hexane afforded $0.13 \mathrm{~g}(78 \%)$ of the title compound as a colorless oil.

The above procedure was repeated in the presence of air and without deoxygenating the reagents or solvent. Molecular sieves were not used in this reaction. The irradiation time was increased to $7 \mathrm{~h}$, and the title compound was isolated in $72 \%$ yield $(0.12 \mathrm{~g})$ after purification by column chromatography (silica: hexane).

Preparation of 2-propoxyltoluene (Table 2, entry 3): Method A. The general method was followed using $2(0.008 \mathrm{~g}, 4.1 \mu \mathrm{mol})$, 2-iodotoluene $(0.11 \mathrm{~mL}, 0.86 \mathrm{mmol})$, crushed molecular sieves $(0.5 \mathrm{~g})$, and $\mathrm{Cs}_{2} \mathrm{CO}_{3}(0.56 \mathrm{~g}, 1.7 \mathrm{mmol})$. The flask was evacuated and refilled with nitrogen, and 1-propanol $(1.5 \mathrm{~mL}, 20 \mathrm{mmol})$ was injected by syringe. After stirring at $110^{\circ} \mathrm{C}$ for 24 hours, the volatiles were evaporated under vacuum and the residue was extracted with hexane and filtered through a plug of silica gel eluting with hexane. Evaporation of the hexane under vacuum afforded $0.105 \mathrm{~g}(81 \%)$ of the title compound as a colorless oil. ${ }^{1} \mathrm{H} \mathrm{NMR}\left(\mathrm{CDCl}_{3}, 25\right.$ $\left.{ }^{\circ} \mathrm{C}\right): \delta 7.16\left(\mathrm{~m}, 2 \mathrm{H},-\mathrm{C}_{6} H_{4} \mathrm{Me}\right), 6.85\left(\mathrm{~m}, 2 \mathrm{H},-\mathrm{C}_{6} \mathrm{H}_{4} \mathrm{Me}\right), 3.95\left(\mathrm{t}, 2 \mathrm{H}, \mathrm{J}=6.4,-\mathrm{OCH}_{2^{-}}\right), 2.25(\mathrm{~m}$, $\left.3 \mathrm{H},-\mathrm{C}_{6} \mathrm{H}_{4} \mathrm{Me}\right), 1.84\left(\mathrm{~m}, 2 \mathrm{H},-\mathrm{CH}_{2^{-}}\right), 1.08\left(\mathrm{t}, 3 \mathrm{H}, \mathrm{J}=7.5,-\mathrm{CH}_{2} \mathrm{Me}\right)$. The above procedure was repeated in the presence of air without deoxygenating the reagents or solvent. Molecular sieves were not used in this reaction. The reaction was stirred at $110{ }^{\circ} \mathrm{C}$ for 48 hours, and the title compound was isolated in $74 \%$ yield $(0.096 \mathrm{~g})$ after purification by column chromatography (silica hexane/ethyl acetate 50:1). 
Preparation of 2-propoxytoluene (Table 2, entry 3): Method B. The general method was followed using 2 ( $0.008 \mathrm{~g}, 4.1 \mu \mathrm{mol})$, 2-iodotoluene $(0.11 \mathrm{~mL}, 0.86 \mathrm{mmol})$, crushed molecular sieves $(0.5 \mathrm{~g})$, and $\mathrm{Cs}_{2} \mathrm{CO}_{3}(0.57 \mathrm{~g}, 1.75 \mathrm{mmol})$. The flask was evacuated and refilled with nitrogen, and 1-propanol $(1.5 \mathrm{~mL}, 12 \mathrm{mmol})$ was added by syringe. The microwave settings were as follows: temperature $=125^{\circ} \mathrm{C}$, maximum microwave power $=50$ watts, maximum pressure $=300 \mathrm{psi}$, and reaction time $=5 \mathrm{~h}$. The maximum power was held until the desired temperature was reached. The magnetron power was decreased to $40 \mathrm{~W}$ (52 psi) in order to maintain the temperature for the remainder of the reaction. Intermittent (not constant) cooling was also used to maintain the temperature these experiments. After the reaction was cooled to room temperature, the volatiles were removed under vacuum, and the reaction mixture was extracted with hexane and filtered through a plug of silica gel $(1 \times 1 \mathrm{~cm})$. Evaporation of the hexane afforded $0.10 \mathrm{~g}(78 \%)$ of the title compound as a colorless oil.

The above procedure was repeated in the presence of air without deoxygenating the reagents or solvent. Molecular sieves were not used in this reaction. The reaction was irradiated for $7 \mathrm{~h}$, and the title compound was isolated in $71 \%$ yield $(0.092 \mathrm{~g})$ after purification by column chromatography (silica hexane/ethyl acetate 50:1).

Preparation of butyloxybenzene (Table 2, entry 4): Method A. The general method was followed using 2 ( $0.008 \mathrm{~g}, 4.1 \mu \mathrm{mol})$, iodobenzene $(0.11 \mathrm{~mL}, 0.98 \mathrm{mmol})$, crushed molecular sieves $(0.5 \mathrm{~g})$, and $\mathrm{Cs}_{2} \mathrm{CO}_{3}(0.64 \mathrm{~g}, 1.96 \mathrm{mmol})$. The flask was evacuated and refilled with nitrogen, and 1-butanol $(1.5 \mathrm{~mL}, 16 \mathrm{mmol})$ was injected by syringe. After stirring at $110{ }^{\circ} \mathrm{C}$ for 11 hours, the volatiles were evaporated under vacuum, and the residue was extracted with hexane and filtered through a short column $(1 \times 1 \mathrm{~cm})$ of silica gel. Evaporation of the hexane under 
vacuum afforded $0.14 \mathrm{~g}(95 \%)$ of the title compound as a colorless oil. ${ }^{1} \mathrm{H} \mathrm{NMR}\left(\mathrm{CDCl}_{3}, 25\right.$ $\left.{ }^{\circ} \mathrm{C}\right): \delta 7.29\left(\mathrm{~m}, 2 \mathrm{H},-\mathrm{C}_{6} H_{5}\right), 6.93\left(\mathrm{~m}, 3 \mathrm{H},-\mathrm{C}_{6} H_{5}\right), 4.00\left(\mathrm{t}, 2 \mathrm{H}, \mathrm{J}=6.5,-\mathrm{OCH}_{2^{-}}\right), 1.78(\mathrm{~m}, 2 \mathrm{H},-$ $\left.\mathrm{CH}_{2^{-}}\right), 1.50\left(\mathrm{~m}, 2 \mathrm{H},-\mathrm{CH}_{2^{-}}\right), 0.98\left(\mathrm{t}, 3 \mathrm{H}, \mathrm{J}=7.4,-\mathrm{CH}_{3}\right)$.

The above procedure was repeated in the presence of air without deoxygenating the reagents or solvent. Molecular sieves were not used in this reaction. The reaction was stirred at $110^{\circ} \mathrm{C}$ for 36 hours, and the title compound was isolated in $81 \%(0.12 \mathrm{~g})$ yield after purification by column chromatography (silica: hexane/ethyl acetate 50:1).

Preparation of butyloxybenzene (Table 2, entry 4): Method B. The general method was followed using $2(0.008 \mathrm{~g}, 4.1 \mu \mathrm{mol})$, iodobenzene $(0.11 \mathrm{~mL}, 0.98 \mathrm{mmol})$, crushed molecular sieves $(0.5 \mathrm{~g})$, and $\mathrm{Cs}_{2} \mathrm{CO}_{3}(0.64 \mathrm{~g}, 1.96 \mathrm{mmol})$. The reactor vial was evacuated and refilled with nitrogen, and 1-butanol $(1.5 \mathrm{~mL}, 16 \mathrm{mmol})$ was injected by syringe. The microwave settings were as follows: temperature $=125^{\circ} \mathrm{C}$, maximum microwave power $=50$ watts, maximum pressure $=300 \mathrm{psi}$, and reaction time $=2 \mathrm{~h}$. The maximum power was held until the desired temperature was reached. The magnetron power was decreased to $40 \mathrm{~W}$ (83 psi) in order to maintain the temperature for the remainder of the reaction. Intermittent cooling was also used to maintain the temperature these experiments. After the reaction was cooled to room temperature, the volatiles were removed under vacuum. The residue was extracted with hexane and filtered through a short column of silica $(1 \mathrm{x} 1 \mathrm{~cm})$. Removal of the hexane afforded $0.13 \mathrm{~g}(88 \%)$ of the title compound as a colorless oil.

The above procedure was repeated in the presence of air without deoxygenating the reagents or solvent. Molecular sieves were not used in this reaction. The reaction was irradiated for $3 \mathrm{~h}$ 
with the same microwave settings as above, and title compound was isolated in $74 \%$ yield $(0.11$ g) after purification by column chromatography (silica: hexane/ethyl acetate 50:1).

Preparation of propyloxybenzene (Table 2, entry 4): Method A. The general method was followed using $2(0.008 \mathrm{~g}, 4.1 \mu \mathrm{mol})$, iodobenzene $(0.11 \mathrm{~mL}, 0.98 \mathrm{mmol})$, and $\mathrm{Cs}_{2} \mathrm{CO}_{3}(0.64 \mathrm{~g}$, $1.96 \mathrm{mmol})$. The flask was evacuated and refilled with nitrogen, and 1-propanol (1.5 mL, 20 mmol) was injected by syringe. After stirring at $110^{\circ} \mathrm{C}$ for 11 hours, the volatiles were evaporated under vacuum, and the residue was extracted with hexane and filtered through a plug of silica gel eluting with hexane. Evaporation of the hexane under vacuum afforded $0.12 \mathrm{~g}$ (90 $\%)$ of the title compound as a colorless oil. ${ }^{1} \mathrm{H}$ NMR $\left(\mathrm{CDCl}_{3}, 25{ }^{\circ} \mathrm{C}\right): \delta 7.29\left(\mathrm{~m}, 2 \mathrm{H},-\mathrm{C}_{6} H_{5}\right)$, $6.90\left(\mathrm{~m}, 3 \mathrm{H},-\mathrm{C}_{6} H_{5}\right), 3.93\left(\mathrm{t}, 2 \mathrm{H}, \mathrm{J}=6.6,-\mathrm{OCH}_{2^{-}}\right), 1.81\left(\mathrm{~m}, 2 \mathrm{H},-\mathrm{CH}_{2^{-}}\right), 1.04(\mathrm{t}, 3 \mathrm{H}, \mathrm{J}=7.4$, $\left.\mathrm{CH}_{2} \mathrm{Me}\right)$.

The above procedure was repeated in the presence of air without deoxygenating the reagents or solvent. Molecular sieves were not used in this reaction. The reaction was stirred at $110^{\circ} \mathrm{C}$ for 36 hours, and the title compound was isolated in $82 \%$ yield $(0.11 \mathrm{~g})$ after purification by column chromatography (silica: hexane/ethyl acetate 50:1).

Preparation of propyloxybenzene (Table 2, entry 4): Method B. The general method was followed using $2(0.008 \mathrm{~g}, 4.1 \mu \mathrm{mol})$, iodobenzene $(0.11 \mathrm{~mL}, 0.98 \mathrm{mmol})$, and $\mathrm{Cs}_{2} \mathrm{CO}_{3}(0.64 \mathrm{~g}$, $1.96 \mathrm{mmol})$. The reactor vial was evacuated and refilled with nitrogen, and 1-propanol (1.5 mL, $20 \mathrm{mmol}$ ) was injected by syringe. The microwave settings were as follows: temperature $=125$ ${ }^{\circ} \mathrm{C}$, maximum microwave power $=50$ watts, maximum pressure $=300 \mathrm{psi}$, and reaction time $=2$ h. The maximum power was held until the desired temperature was reached. The magnetron 
power was decreased to $39 \mathrm{~W}$ (48 psi) in order to maintain the temperature for the remainder of the reaction. Intermittent cooling was also used to maintain the temperature these experiments. After the reaction was cooled to room temperature, the volatiles were removed under vacuum. The residue was extracted with hexane and filtered through a short plug of silica. Evaporation of the hexane afforded $0.114 \mathrm{~g}(85 \%)$ of the title compound as a colorless oil.

The above procedure was repeated in the presence of air without deoxygenating the reagents or solvent. Molecular sieves were not used in this reaction. The reaction was irradiated for $3 \mathrm{~h}$ with the same microwave settings as above, and title compound was isolated in $75 \%(0.11 \mathrm{~g})$ yield after purification by column chromatography (silica: hexane/ethyl acetate 50:1).

Preparation of 4-heptyloxyaniline (Table 2, entry 5): Method A. The general procedure was followed with 2 (0.008 g, $4.1 \mu \mathrm{mol})$, 4-iodoaniline (0.2 g, $0.91 \mathrm{mmol})$, crushed molecular sieves $(0.5 \mathrm{~g})$, and $\mathrm{Cs}_{2} \mathrm{CO}_{3}(0.60 \mathrm{~g}, 1.8 \mathrm{mmol})$. The flask was evacuated and refilled with nitrogen, and 1-heptanol (1.5 mL, $10.6 \mathrm{mmol})$, was added by syringe. After stirring at $110{ }^{\circ} \mathrm{C}$ for 11 hours, the reaction mixture was filtered through silica gel $(1 \times 1 \mathrm{~cm})$ and the volatiles were evaporated. Purification by column chromatography (silica: hexane/ethyl acetate $2: 1$ ) afforded $0.15 \mathrm{~g}(80 \%$ ) of the title compound as a red-brown solid. ${ }^{1} \mathrm{H} \mathrm{NMR}\left(\mathrm{CDCl}_{3}, 25{ }^{\circ} \mathrm{C}\right): \delta 6.76(\mathrm{~d}, 2 \mathrm{H}, \mathrm{J}=8.8$, $\left.\mathrm{C}_{6} \mathrm{H}_{4} \mathrm{NH}_{2}\right), 6.65\left(\mathrm{~d}, 2 \mathrm{H}, \mathrm{J}=8.8,-\mathrm{C}_{6} \mathrm{H}_{4} \mathrm{NH}_{2}\right), 3.89$ (t, 2H, J = 6.6, -OCH $2_{2}$ ), 3.40 (br s, 2H, $\left.\mathrm{C}_{6} \mathrm{H}_{4} \mathrm{NH}_{2}\right), 1.76\left(\mathrm{~m}, 2 \mathrm{H},-\mathrm{CH}_{2^{-}}\right), 1.47-1.30\left(\mathrm{~m}, 8 \mathrm{H},-\mathrm{CH}_{2^{-}}\right), 0.91\left(\mathrm{t}, 3 \mathrm{H}, \mathrm{J}=6.6,-\mathrm{CH}_{2} \mathrm{Me}\right)$. The above procedure was repeated in the presence of air without deoxygenating the reagents or solvent. Molecular sieves were not used in this reaction. The reaction mixture was stirred at 110 ${ }^{\circ} \mathrm{C}$ for 36 hours, and the title compound was isolated in $69 \%$ yield $(0.13 \mathrm{~g})$. 
Preparation of 4-heptyloxyaniline (Table 2, entry 5): Method B. The general procedure was followed with 2 (0.008 g, $4.1 \mu \mathrm{mol})$, 4-iodoaniline (0.2 g, $0.91 \mathrm{mmol})$, crushed molecular sieves (0.5 g), and $\mathrm{Cs}_{2} \mathrm{CO}_{3}(0.60 \mathrm{~g}, 1.8 \mathrm{mmol})$. The reactor vial was evacuated and refilled with nitrogen, and 1-heptanol $(1.5 \mathrm{~mL}, 10.6 \mathrm{mmol})$ was added by syringe. The microwave settings were as follows: temperature $=125^{\circ} \mathrm{C}$, maximum microwave power $=50$ watts, maximum pressure $=300 \mathrm{psi}$, and reaction time $=3 \mathrm{~h}$. The maximum power was held until the desired temperature was reached. The magnetron power was decreased to $35 \mathrm{~W}$ (16 psi) in order to maintain the temperature for the remainder of the reaction. Intermittent cooling was also used to maintain the temperature these experiments. After the reaction was cooled to room temperature, the reaction mixture was filtered through silica gel $(1 \times 1 \mathrm{~cm})$, and the volatiles were removed under vacuum. Purification by column chromatography (silica: hexane/ethyl acetate 2:1) afforded $0.14 \mathrm{~g}(74 \%)$ of the title compound as a brown-red solid.

The above procedure was repeated in the presence of air without deoxygenating the reagents or solvent. Molecular sieves were not used in this reaction. The reaction was irradiated for $4 \mathrm{~h}$ with the same microwave settings as above, and title compound was isolated in $69 \%$ yield $(0.13$ g).

Preparation of 4-propyloxyaniline (Table 2, entry 5): Method A. The general procedure was followed with 2 (0.008 g, $4.1 \mu \mathrm{mol})$, 4-iodoaniline $(0.2 \mathrm{~g}, 0.91 \mathrm{mmol})$, crushed molecular sieves $(0.5 \mathrm{~g})$, and $\mathrm{Cs}_{2} \mathrm{CO}_{3}(0.60 \mathrm{~g}, 1.8 \mathrm{mmol})$. The flask was evacuated and refilled with nitrogen, and 1-propanol $(1.5 \mathrm{~mL}, 20 \mathrm{mmol})$ was added by syringe. After stirring at $110^{\circ} \mathrm{C}$ for 11 hours, the reaction mixture was passed through a short plug of silica and the volatiles were removed under vacuum with gentle heating. Purification of the residue by column chromatography (silica: 
hexanes/ethyl acetate $2: 1)$ afforded $0.10 \mathrm{~g}(73 \%)$ of the title compound as a brown-red oil. ${ }^{1} \mathrm{H}$ $\operatorname{NMR}\left(\mathrm{CDCl}_{3} 25^{\circ} \mathrm{C}\right): \delta 6.76\left(\mathrm{~d}, 2 \mathrm{H}, \mathrm{J}=8.6,-\mathrm{C}_{6} \mathrm{H}_{4} \mathrm{NH}_{2}\right), 6.65\left(\mathrm{~d}, 2 \mathrm{H}, \mathrm{J}=8.6,-\mathrm{C}_{6} H_{4} \mathrm{NH}_{2}\right), 3.85$ $\left(\mathrm{t}, 2 \mathrm{H}, \mathrm{J}=6.6,-\mathrm{OCH}_{2^{-}}\right), 3.32\left(\mathrm{br} \mathrm{s}, 2 \mathrm{H},-\mathrm{NH}_{2}\right), 1.78\left(\mathrm{~m}, 2 \mathrm{H},-\mathrm{CH}_{2^{-}}\right), 1.03(\mathrm{t}, 3 \mathrm{H}, \mathrm{J}=5.3$, $\left.\mathrm{CH}_{2} \mathrm{Me}\right)$.

The above procedure was repeated in the presence of air without deoxygenating the reagents or solvent. Molecular sieves were not used in this reaction. The reaction was stirred at $110{ }^{\circ} \mathrm{C}$ for 36 hours, and the title compound was isolated in $55 \%(0.075 \mathrm{~g})$ yield.

Preparation of 4-propyloxyaniline (Table 2, entry 5): Method B. The general procedure was followed with 2 (0.008 g, $4.1 \mu \mathrm{mol})$, 4-iodoaniline (0.2 g, $0.91 \mathrm{mmol})$, crushed molecular sieves (0.5 g), and $\mathrm{Cs}_{2} \mathrm{CO}_{3}(0.60 \mathrm{~g}, 1.8 \mathrm{mmol})$. The microwave reactor vial was evacuated and refilled with nitrogen, and charged with 1-propanol $(1.5 \mathrm{~mL}, 20 \mathrm{mmol})$. The microwave settings were as follows: temperature $=125^{\circ} \mathrm{C}$, maximum microwave power $=50$ watts, maximum pressure $=$ $300 \mathrm{psi}$, and reaction time $=3 \mathrm{~h}$. The maximum power was held until the desired temperature was reached. The magnetron power was decreased to $45 \mathrm{~W}$ (54 psi) in order to maintain the temperature for the remainder of the reaction. Intermittent (not active) cooling was also used to maintain the temperature these experiments. The reactor vial was cooled to $50{ }^{\circ} \mathrm{C}$, the reaction mixture was passed through a short plug of silica gel, and the volatiles were evacuated under vacuum. Purification by column chromatography (silica: hexane/ethyl acetate 2:1) afforded $0.095 \mathrm{~g}(69 \%)$ of the title compound as a red-brown oil.

The above procedure was repeated in the presence of air without deoxygenating the reagents or solvent. Molecular sieves were not used in this reaction. The reaction was irradiated for $4 \mathrm{~h}$ with the same microwave settings as above, and title compound was isolated in $65 \%(0.089 \mathrm{~g})$ yield 
Reaction of 4-iodonitrobenzene with hexyl alcohol (Table 2, entry 6): Method A. The general procedure was followed with 2 (0.008 g, $4.1 \mu \mathrm{mol}), 4$-iodonitrotoluene $(0.2 \mathrm{~g}, 0.80$ mmol), crushed molecular sieves $(0.5 \mathrm{~g})$, and $\mathrm{Cs}_{2} \mathrm{CO}_{3}(0.53 \mathrm{~g}, 1.6 \mathrm{mmol})$. The reaction flask was evacuated and refilled with nitrogen, and 1-hexanol $(1.5 \mathrm{~mL}, 12 \mathrm{mmol})$ was added by syringe. The reaction was stirred at $110^{\circ} \mathrm{C}$ for 11 hours, cooled to room temperature, filtered through a small plug of silica gel, and dried under vacuum with gentle heating. Analysis of the residue by GC and NMR revealed a mixture of 4-hexyloxynitrobenzene and 4-hexyloxyaniline.

The above procedure was repeated in the presence of air without deoxygenating the reagents or solvent. Molecular sieves were not used in this reaction. The reaction mixture was stirred for 36 h at $110^{\circ} \mathrm{C}$. Analysis by GC and NMR spectroscopy revealed a mixture of $4-$ hexyloxynitrobenzene and 4-hexyloxyaniline.

\section{Reaction of 4-iodonitrobenzene with hexyl alcohol (Table 2, entry 6): Method A. The} general procedure was followed with $2(0.008 \mathrm{~g}, 4.1 \mu \mathrm{mol}), 4$-iodonitrotoluene $(0.2 \mathrm{~g}, 0.80$ mmol), crushed molecular sieves $(0.5 \mathrm{~g})$, and $\mathrm{Cs}_{2} \mathrm{CO}_{3}(0.53 \mathrm{~g}, 1.6 \mathrm{mmol})$. The reactor flask was evacuated and refilled with nitrogen, and hexyl alcohol $(1.5 \mathrm{~mL}, 12 \mathrm{mmol})$ was added by syringe. The microwave settings were as follows: temperature $=125^{\circ} \mathrm{C}$, maximum microwave power $=50$ watts, maximum pressure $=300 \mathrm{psi}$, and reaction time $=1 \mathrm{~h}$. The maximum power was held until the desired temperature was reached. The magnetron power was decreased to $35 \mathrm{~W}(17 \mathrm{psi})$ in order to maintain the temperature for the remainder of the reaction. Intermittent cooling was also used to maintain the temperature these experiments. The reaction was cooled to room temperature, filtered through a small plug of silica gel, and dried under 
vacuum with gentle heating. Analysis of the residue by GC and NMR revealed a mixture of 4hexyloxynitrobenzene and 4-hexyloxyaniline.

The above procedure was repeated in the presence of air without deoxygenating the reagents or solvent. Molecular sieves were not used in this reaction. The reaction was irradiated for $1 \mathrm{~h}$ with the same settings as above. Analysis of the residue by GC and NMR revealed a mixture of 4-hexyloxynitrobenzene and 4-hexyloxyaniline.

Reaction of 4-iodonitrobenzene with 1-heptanol (Table 2, entry 6): Method A. The general procedure was followed with $2(0.008 \mathrm{~g}, 4.1 \mu \mathrm{mol})$, 4-iodonitrotoluene $(0.2 \mathrm{~g}, 0.80 \mathrm{mmol})$, $\mathrm{Cs}_{2} \mathrm{CO}_{3}(0.53 \mathrm{~g}, 1.6 \mathrm{mmol})$, and molecular sieves $(0.5 \mathrm{~g})$. The reactor flask was evacuated and refilled with nitrogen, and heptanol $(1.5 \mathrm{~mL}, 11 \mathrm{mmol})$ was added by syringe. After stirring at $110^{\circ} \mathrm{C}$ for 11 hours, The reaction was cooled to room temperature, filtered through a small plug of silica gel, and dried under vacuum with gentle heating. Analysis of the residue by GC and NMR revealed a mixture of 4-heptyloxynitrobenzene and 4-heptyloxyaniline.

The above procedure was repeated in the presence of air without deoxygenating the reagents or solvent. The reaction mixture was stirred at $110^{\circ} \mathrm{C}$ for 36 hours. Analysis of the residue by GC and NMR revealed a mixture of 4-heptyloxynitrobenzene and 4-heptyloxyaniline.

Reaction of 4-iodonitrobenzene with 1-heptanol (Table 2, entry 6): Method B. The general procedure was followed with $2(0.008 \mathrm{~g}, 4.1 \mu \mathrm{mol})$, 4-iodonitrotoluene $(0.2 \mathrm{~g}, 0.80 \mathrm{mmol})$, $\mathrm{Cs}_{2} \mathrm{CO}_{3}(0.53 \mathrm{~g}, 1.6 \mathrm{mmol})$, and molecular sieves $(0.5 \mathrm{~g})$. The reactor flask was evacuated and refilled with nitrogen, and 1-heptanol $(1.5 \mathrm{~mL}, 11 \mathrm{mmol})$ was added by syringe. The microwave settings were as follows: temperature $=125^{\circ} \mathrm{C}$, maximum microwave power $=50$ watts, 
maximum pressure $=300 \mathrm{psi}$, and reaction time $=1 \mathrm{~h}$. The maximum power was held until the desired temperature was reached. The magnetron power was decreased to $39 \mathrm{~W}$ (16 psi) in order to maintain the temperature for the remainder of the reaction. Intermittent cooling was also used to maintain the temperature these experiments. After the reaction was cooled to room temperature, the reaction mixture was filtered through a small plug of silica gel, and the volatiles were removed under vacuum. Analysis of the residue by GC and NMR revealed a mixture of 4heptyloxynitrobenzene and 4-heptyloxyaniline.

The above procedure was repeated in the presence of air without deoxygenating the reagents or solvent. Molecular sieves were not used in this reaction. The reaction mixture was irradiated for 1 hour. Analysis of the residue by GC and NMR revealed a mixture of 4-heptyloxynitrobenzene and 4-heptyloxyaniline.

Preparation of 4-hexyloxychlorobenzene (Table 2, entry 7): Method A. The general method was followed using 2 ( $0.008 \mathrm{~g}, 4.1 \mathrm{mmol})$, 4-iodochlorobenzene $(0.20 \mathrm{~g}, 0.84 \mathrm{mmol})$, crushed molecular sieves $(0.5 \mathrm{~g})$, and $\mathrm{Cs}_{2} \mathrm{CO}_{3}(0.56,1.7 \mathrm{mmol})$. The flask was evacuated and refilled with nitrogen, and hexyl alcohol $(1.5 \mathrm{~mL}, 12 \mathrm{mmol})$ was injected by syringe. After stirring at $110^{\circ} \mathrm{C}$ for 11 hours, the volatiles were evaporated under vacuum. The residue was extracted with hexane and filtered through a plug of silica gel eluting with hexane. Evaporation of the hexane under vacuum afforded $0.16 \mathrm{~g}(89 \%)$ of the title compound as a colorless oil. The ${ }^{1} \mathrm{H}$ and ${ }^{13} \mathrm{C}\left\{{ }^{1} \mathrm{H}\right\}$ NMR spectra are shown after the experimental descriptions. ${ }^{1} \mathrm{H}$ NMR $\left(\mathrm{CDCl}_{3}, 25{ }^{\circ} \mathrm{C}\right)$ : $\delta 7.21\left(\mathrm{~d}, 2 \mathrm{H}, \mathrm{J}=8.5,-\mathrm{C}_{6} \mathrm{H}_{4} \mathrm{Cl}\right), 6.81\left(\mathrm{~d}, 2 \mathrm{H}, \mathrm{J}=8.5,-\mathrm{C}_{6} \mathrm{H}_{4} \mathrm{Cl}\right), 3.89\left(\mathrm{t}, 2 \mathrm{H}, \mathrm{J}=6.5,-\mathrm{OCH}_{2^{-}}\right)$, $1.74\left(\mathrm{~m}, 2 \mathrm{H},-\mathrm{CH}_{2^{-}}\right), 1.42\left(\mathrm{~m}, 2 \mathrm{H},-\mathrm{CH}_{2^{-}}\right), 1.32\left(\mathrm{~m}, 4 \mathrm{H},-\mathrm{CH}_{2^{-}}\right), 0.91\left(\mathrm{t}, 3 \mathrm{H}, \mathrm{J}=6.3,-\mathrm{CH}_{3}\right)$. 
The above procedure was repeated in the presence of air without deoxygenating the reagents or solvent. Molecular sieves were not used in this reaction. The reaction was stirred at $110{ }^{\circ} \mathrm{C}$ for 36 hours, and the title compound was isolated in $84 \%(0.15 \mathrm{~g})$ yield after purification by column chromatography (silica: hexane/ethyl acetate 30:1).

\section{Preparation of 4-hexyloxychlorobenzene (Table 2, entry 7): Method B. The general} procedure was followed with $2(0.008 \mathrm{~g}, 4.1 \mu \mathrm{mol})$, 4-iodochlorobenzene $(0.20 \mathrm{~g}, 0.84 \mathrm{mmol})$, $\mathrm{Cs}_{2} \mathrm{CO}_{3}(0.56 \mathrm{~g}, 1.7 \mathrm{mmol})$, and molecular sieves $(0.5 \mathrm{~g})$. The microwave vial was evacuated and refilled with nitrogen, and hexyl alcohol $(1.5 \mathrm{~mL}, 12 \mathrm{mmol})$ was injected by syringe. The microwave settings were as follows: temperature $=125^{\circ} \mathrm{C}$, maximum microwave power $=50$ watts, maximum pressure $=300 \mathrm{psi}$, and reaction time $=2 \mathrm{~h}$. The maximum power was held until the desired temperature was reached. The magnetron power was decreased to $40 \mathrm{~W}$ (17 psi) in order to maintain the temperature for the remainder of the reaction. Intermittent cooling was also used to maintain the temperature these experiments. After the reaction mixture was cooled to room temperature, the volatiles were removed under vacuum. The residue was extracted with hexane and filtered through a plug $(1 \mathrm{x} 1 \mathrm{~cm})$ of silica gel. Evaporation of the hexane afforded $0.15 \mathrm{~g}(84 \%)$ of the title compound as colorless oil.

The above procedure was repeated in the presence of air without deoxygenating the reagents or solvent. Molecular sieves were not used in this reaction. The reaction was irradiated for $3 \mathrm{~h}$ with the same microwave settings as above, and title compound was isolated in $79 \%(0.14 \mathrm{~g})$ yield after purification by column chromatography (silica: hexane/ethyl acetate 30:1). 
Preparation of 4-propyloxychlorobenzene (Table 2, entry 7): Method A. The general method was followed using $2(0.008 \mathrm{~g}, 4.1 \mu \mathrm{mol})$, 4-iodochlorobenzene $(0.2 \mathrm{~g}, 0.84 \mathrm{mmol}), \mathrm{Cs}_{2} \mathrm{CO}_{3}$ (0.56 g, $1.7 \mathrm{mmol})$, and molecular sieves $(0.5 \mathrm{~g})$. The flask was evacuated and refilled with nitrogen, and 1-propanol $(1.5 \mathrm{~mL}, 20 \mathrm{mmol})$ was injected by syringe. After stirring at $110{ }^{\circ} \mathrm{C}$ for 11 hours, the volatiles were evaporated under vacuum, and the residue was extracted with hexane and filtered through a plug of silica gel eluting with hexane. Evaporation of the hexane afforded $0.12 \mathrm{~g}(84 \%)$ of the title compound as a colorless oil. The ${ }^{1} \mathrm{H}$ and ${ }^{13} \mathrm{C}\left\{{ }^{1} \mathrm{H}\right\}$ NMR spectra are shown after the experimental descriptions. ${ }^{1} \mathrm{H} \mathrm{NMR}\left(\mathrm{CDCl}_{3}, 25{ }^{\circ} \mathrm{C}\right): \delta 7.23(\mathrm{~d}, 2 \mathrm{H}, \mathrm{J}=8.8$, $\left.\mathrm{C}_{6} \mathrm{H}_{4} \mathrm{Cl}\right), 6.83\left(\mathrm{~d}, 2 \mathrm{H},-\mathrm{C}_{6} \mathrm{H}_{4} \mathrm{Cl}\right), 3.89\left(\mathrm{t}, 2 \mathrm{H}, \mathrm{J}=6.7,-\mathrm{OCH}_{2^{-}}\right), 1.81\left(\mathrm{~m}, 2 \mathrm{H},-\mathrm{CH}_{2^{-}}\right), 1.05(\mathrm{~m}, 3 \mathrm{H}$, $\left.\mathrm{J}=7.4,-\mathrm{CH}_{3}\right)$

The above procedure was repeated in the presence of air without deoxygenating the reagents or solvent. Molecular sieves were not used in this reaction. The reaction was stirred at $110{ }^{\circ} \mathrm{C}$ for 36 hours, and the title compound was isolated in $77 \%(0.11 \mathrm{~g})$ yield after purification by column chromatography (silica: hexane/ethyl acetate 10:1).

Preparation of 4-propyloxychlorobenzene (Table 2, entry 7): Method B. The general method was followed using $2(0.008 \mathrm{~g}, 4.1 \mu \mathrm{mol})$, iodochlorobenzene $(0.2 \mathrm{~g}, 0.84 \mathrm{mmol})$, $\mathrm{Cs}_{2} \mathrm{CO}_{3}(0.55 \mathrm{~g}, 1.7 \mathrm{mmol})$, and crushed molecular sieves $(0.5 \mathrm{~g})$. The reactor vial was evacuated and refilled with nitrogen, and 1-propanol $(1.5 \mathrm{~mL}, 20 \mathrm{mmol})$ was injected by syringe. The microwave settings were as follows: temperature $=125^{\circ} \mathrm{C}$, maximum microwave power $=$ 50 watts, maximum pressure $=300 \mathrm{psi}$, and reaction time $=2 \mathrm{~h}$. The maximum power was held until the desired temperature was reached. The magnetron power was decreased to $42 \mathrm{~W}$ (55 psi) in order to maintain the temperature for the remainder of the reaction. Intermittent cooling 
was also used to maintain the temperature these experiments. The reaction was cooled to room temperature, and the volatiles were evaporated under vacuum. The residue was extracted with hexane and filtered through a plug of silica gel $(1 \mathrm{x} 1 \mathrm{~cm})$. Evaporation of the hexane afforded $0.11 \mathrm{~g}(77 \%)$ of the title compound as a colorless oil. The above procedure was repeated in the presence of air without deoxygenating the reagents or solvent. Molecular sieves were not used in this reaction. The reaction was irradiated for $3 \mathrm{~h}$ with the same microwave settings as above, and title compound was isolated in $70 \%(0.10 \mathrm{~g})$ yield after purification by column chromatography (silica hexane/ethylacetate 10:1). 
The NMR spectra shown below were processed using NUTS.

${ }^{1} \mathrm{H}$ NMR spectrum of $2\left(\mathrm{CDCl}_{3}, 25^{\circ} \mathrm{C}\right)$. ${ }^{*}$ Solvent impurity $\left(\mathrm{H}_{2} \mathrm{O}\right)$.

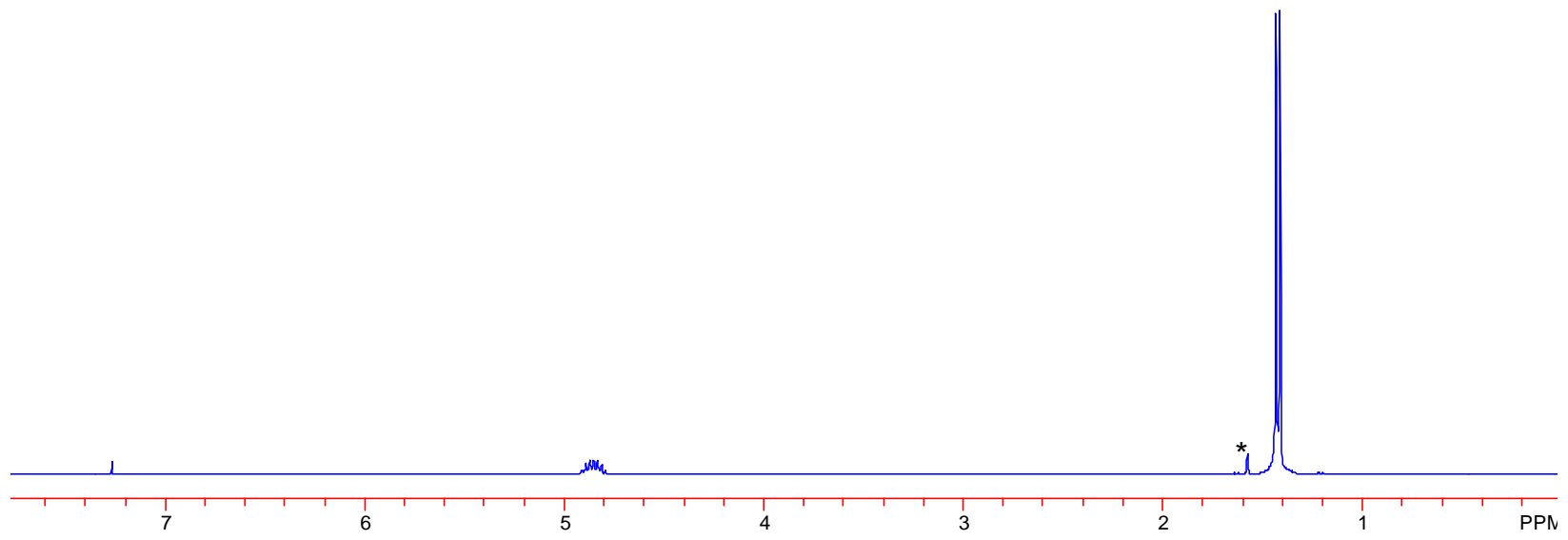

${ }^{31} \mathrm{P}\left\{{ }^{1} \mathrm{H}\right\}$ NMR spectrum of $2\left(\mathrm{CDCl}_{3}, 25^{\circ} \mathrm{C}\right)$.

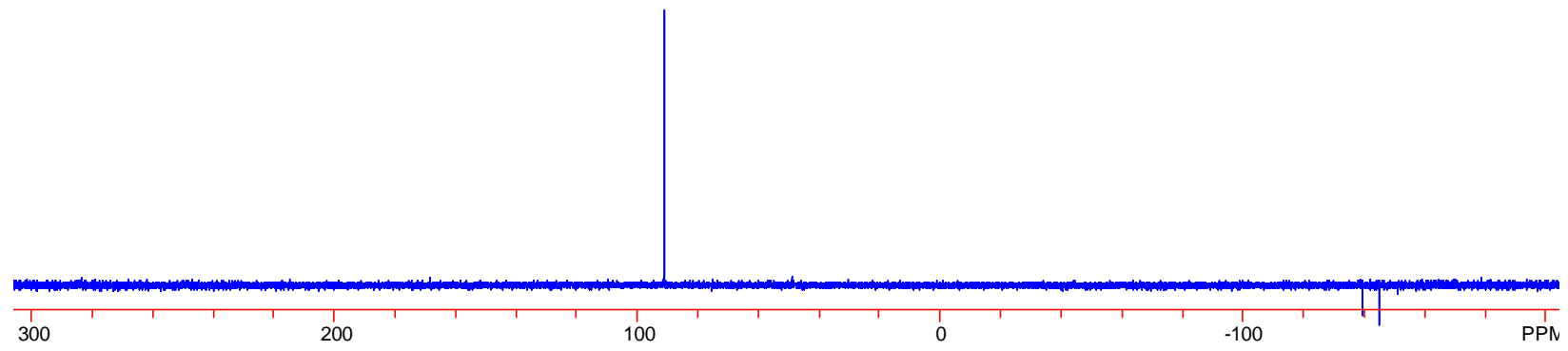


${ }^{1} \mathrm{H}$ NMR spectrum $\left(\mathrm{CDCl}_{3}, 25^{\circ} \mathrm{C}\right)$ of 4-tetrafurfuryloxytoluene (Method A-degassed).

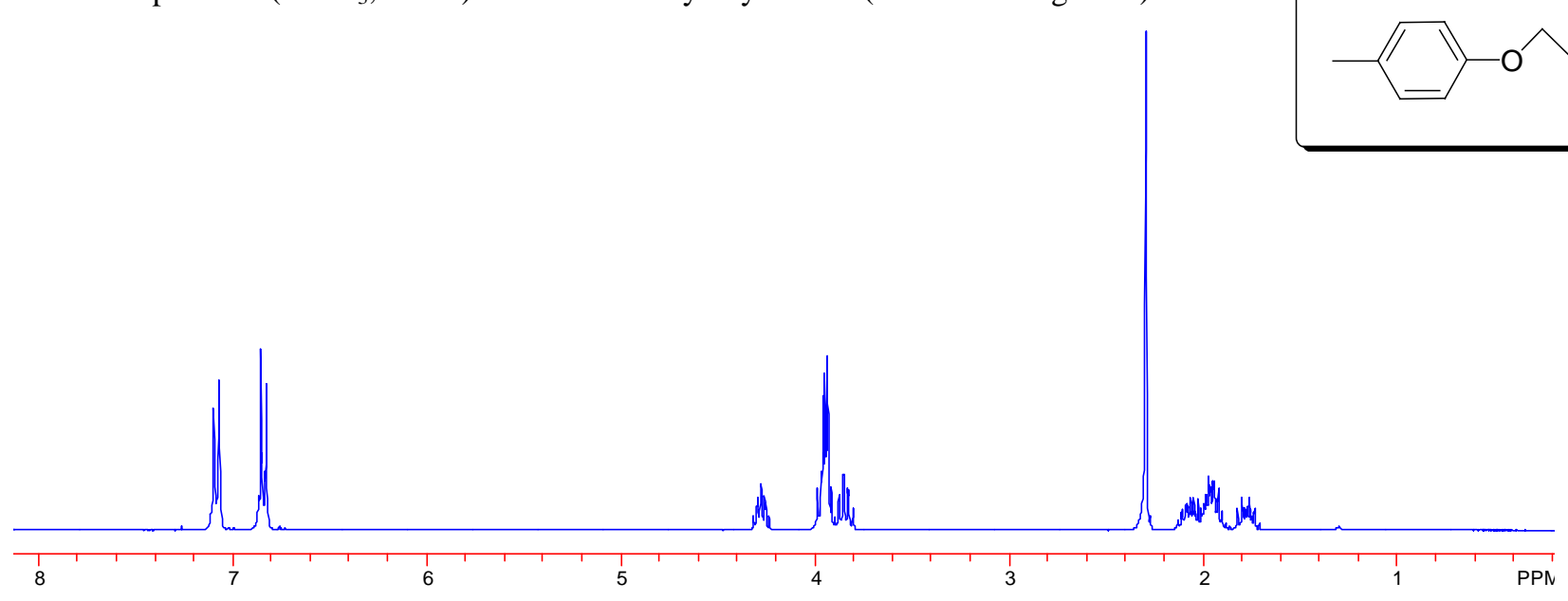

${ }^{13} \mathrm{C}\left\{{ }^{1} \mathrm{H}\right\}$ NMR spectrum $\left(\mathrm{CDCl}_{3}, 25^{\circ} \mathrm{C}\right)$ of 4-tetrafurfuryloxytoluene (Method A-degassed).

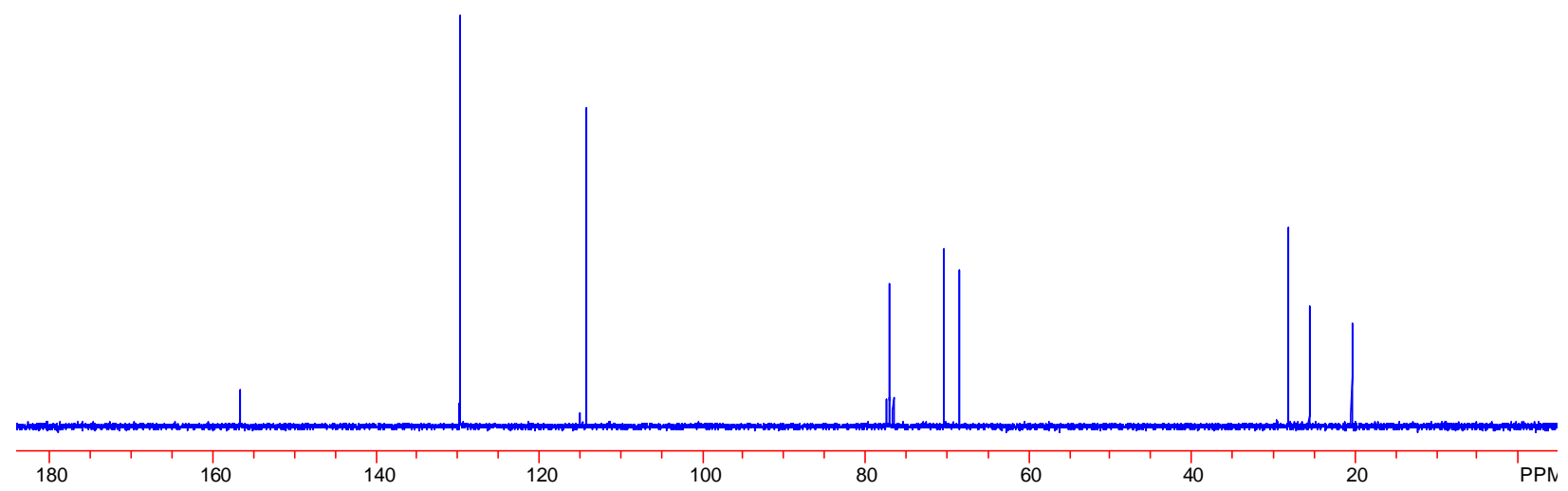

${ }^{13} \mathrm{C}\left\{{ }^{1} \mathrm{H}\right\}$ DEPT135 NMR spectrum $\left(\mathrm{CDCl}_{3}, 25{ }^{\circ} \mathrm{C}\right)$ of 4-tetrafurfuryloxytoluene (Method A-degassed).

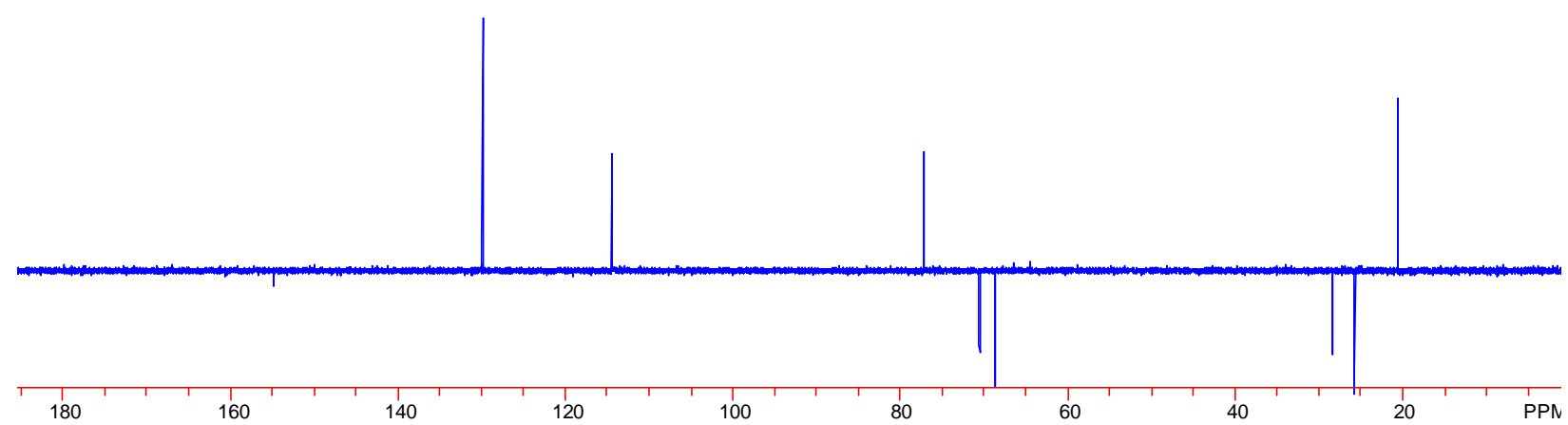


${ }^{1} \mathrm{H}$ NMR spectrum $\left(\mathrm{CDCl}_{3}, 25^{\circ} \mathrm{C}\right)$ of 2-tetrafurfuryloxytoluene (Method B-degassed).
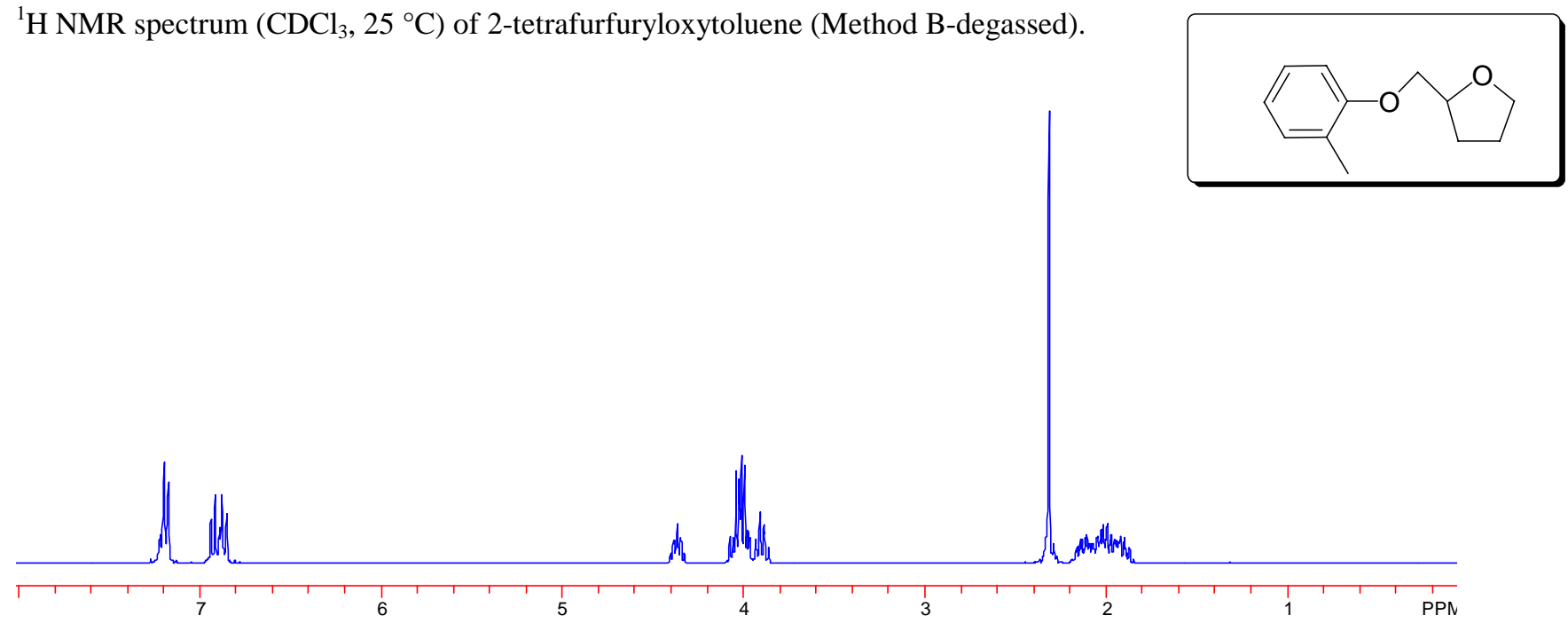

${ }^{13} \mathrm{C}\left\{{ }^{1} \mathrm{H}\right\}$ NMR spectrum $\left(\mathrm{CDCl}_{3}, 25^{\circ} \mathrm{C}\right)$ of 2-tetrafurfuryloxytoluene (Method B-degassed).

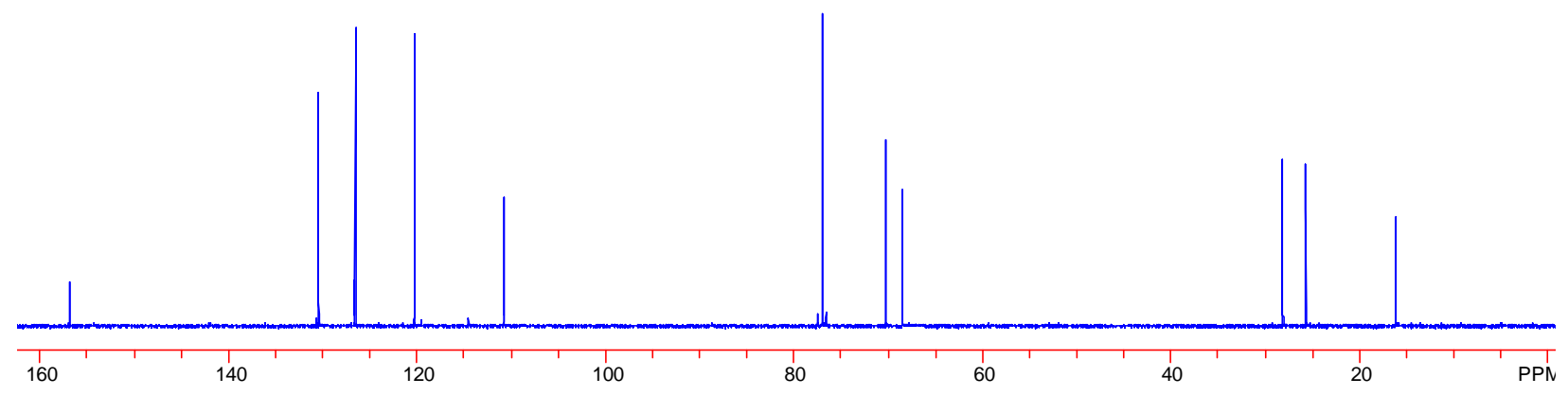

${ }^{13} \mathrm{C}\left\{{ }^{1} \mathrm{H}\right\}$ DEPT135 NMR spectrum $\left(\mathrm{CDCl}_{3}, 25{ }^{\circ} \mathrm{C}\right)$ of 2-tetrafurfuryloxytoluene (Method B-degassed).

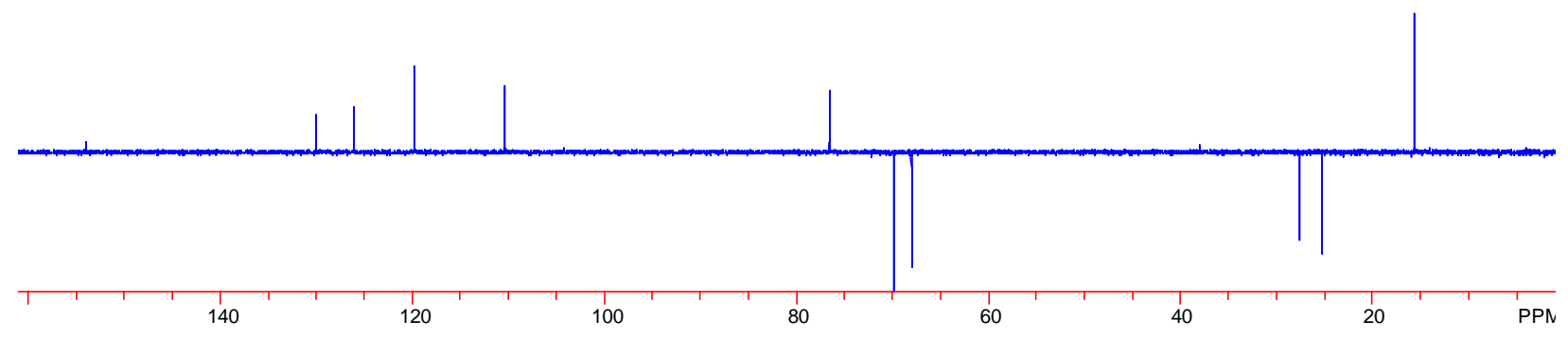


${ }^{1} \mathrm{H}$ NMR spectrum $\left(\mathrm{CDCl}_{3}, 25^{\circ} \mathrm{C}\right)$ of 2-tetrafurfuryloxyanisole (Method A-under air).

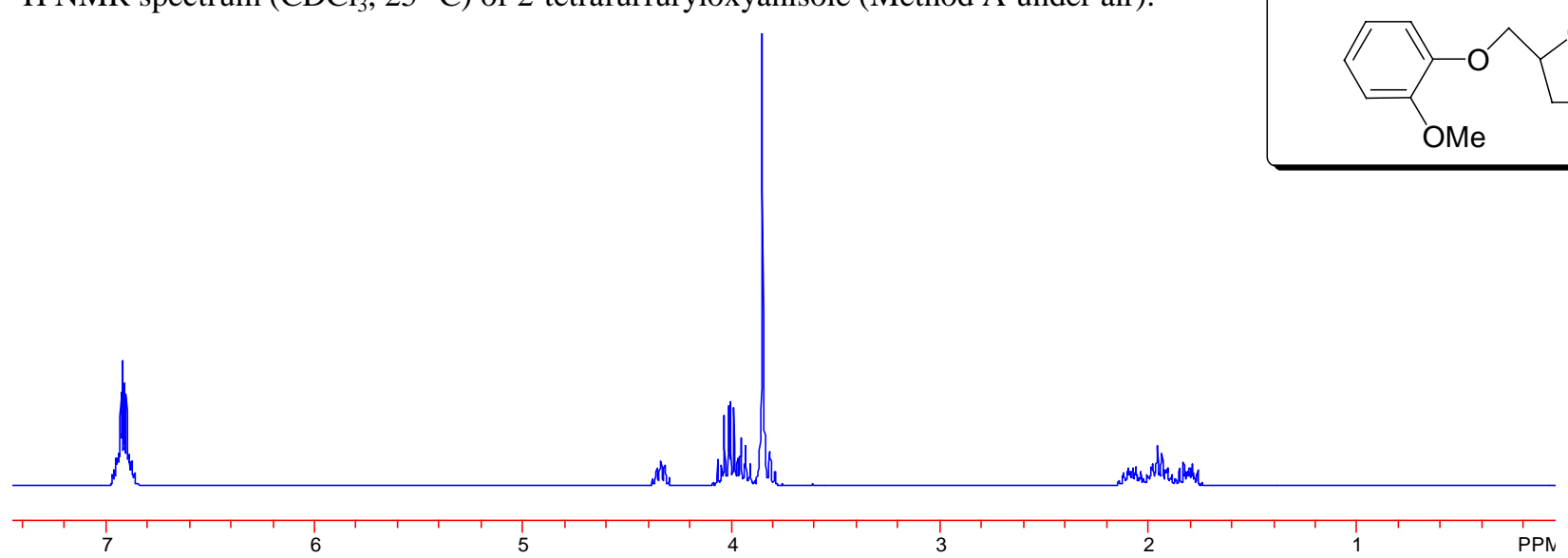

${ }^{13} \mathrm{C}\left\{{ }^{1} \mathrm{H}\right\}$ NMR spectrum $\left(\mathrm{CDCl}_{3}, 25{ }^{\circ} \mathrm{C}\right)$ of 2-tetrafurfuryloxyanisole (Method A-under air).

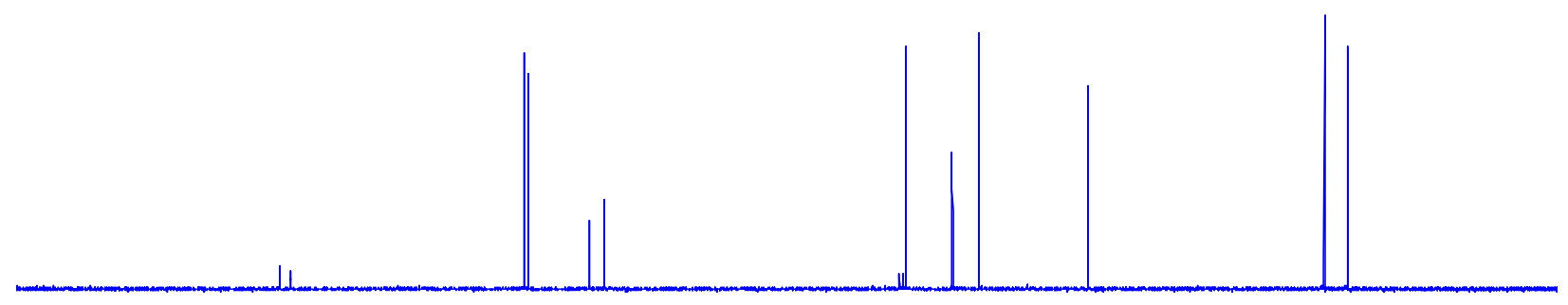

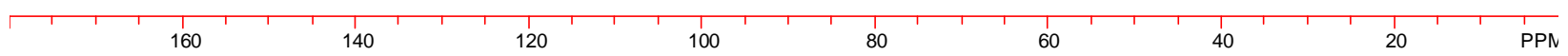

${ }^{13} \mathrm{C}\left\{{ }^{1} \mathrm{H}\right\}$ DEPT135 NMR spectrum $\left(\mathrm{CDCl}_{3}, 25{ }^{\circ} \mathrm{C}\right)$ of 2-tetrafurfuryloxyanisole (Method A-under air).

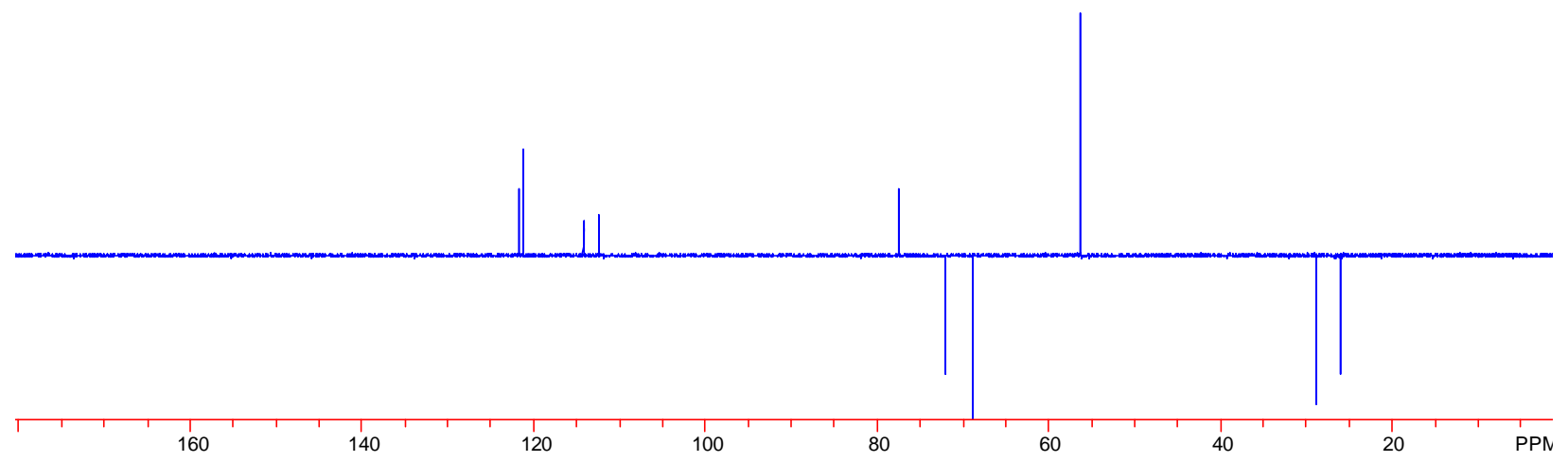


${ }^{1} \mathrm{H}$ NMR $\left(\mathrm{CDCl}_{3}, 25^{\circ} \mathrm{C}\right)$ spectrum of 4-propyloxytoluene after removal of the volatiles and filtration through a short column $(1 \mathrm{x} 1 \mathrm{~cm})$ of silica (no chromatography:

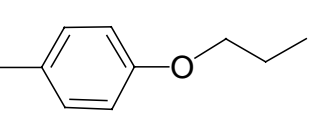
Method A-degassed).

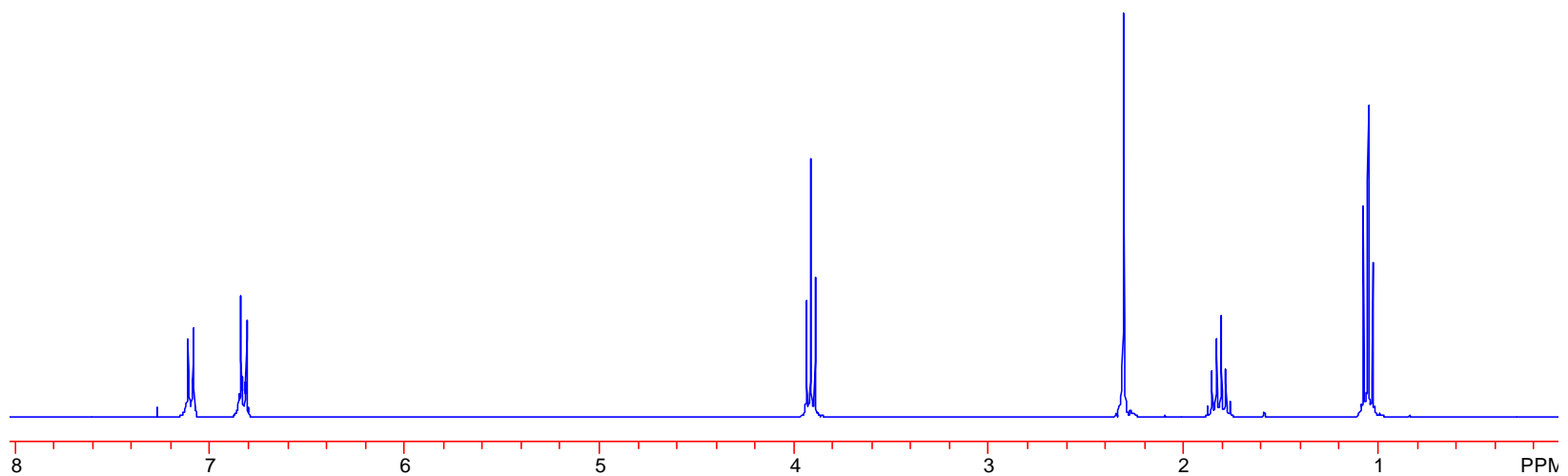

${ }^{13} \mathrm{C}\left\{{ }^{1} \mathrm{H}\right\}$ NMR $\left(\mathrm{CDCl}_{3}, 25^{\circ} \mathrm{C}\right)$ spectrum of 4-propyloxytoluene after removal

of the volatiles and filtration through a short column $(1 \mathrm{x} 1 \mathrm{~cm})$ of silica (no chromatography: Method A-degassed).

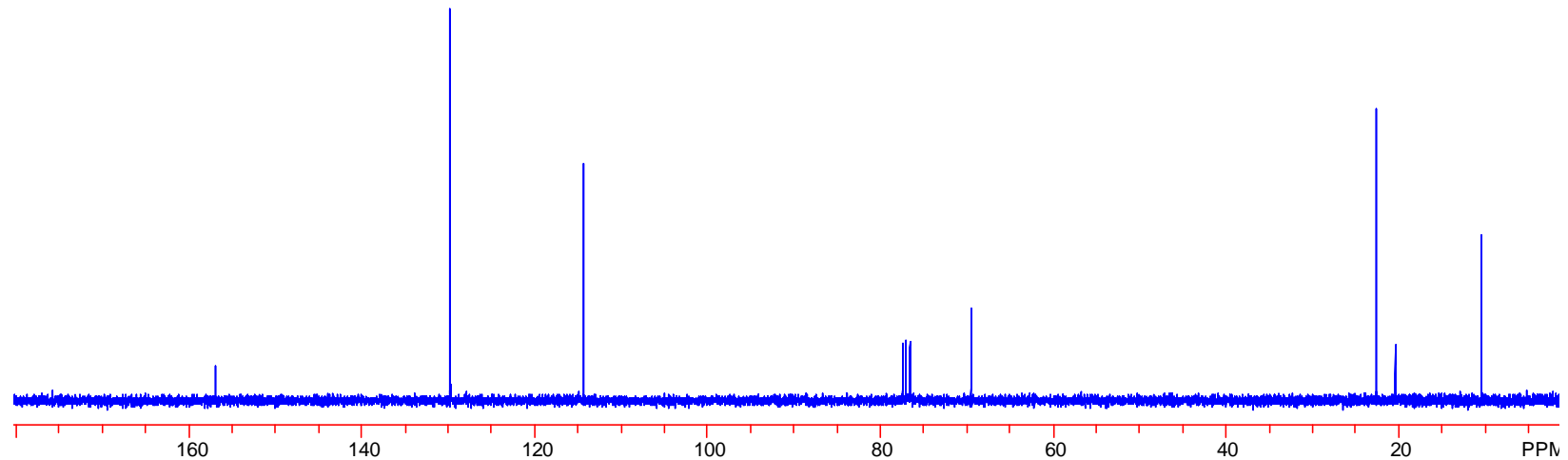


${ }^{1} \mathrm{H}$ NMR $\left(\mathrm{CDCl}_{3}, 25^{\circ} \mathrm{C}\right)$ spectrum of 4-hexyloxychlorobenzene after removal of the volatiles and filtration through a short column $(1 \times 1 \mathrm{~cm})$ of silica (no chromatography: Method A-degassed).

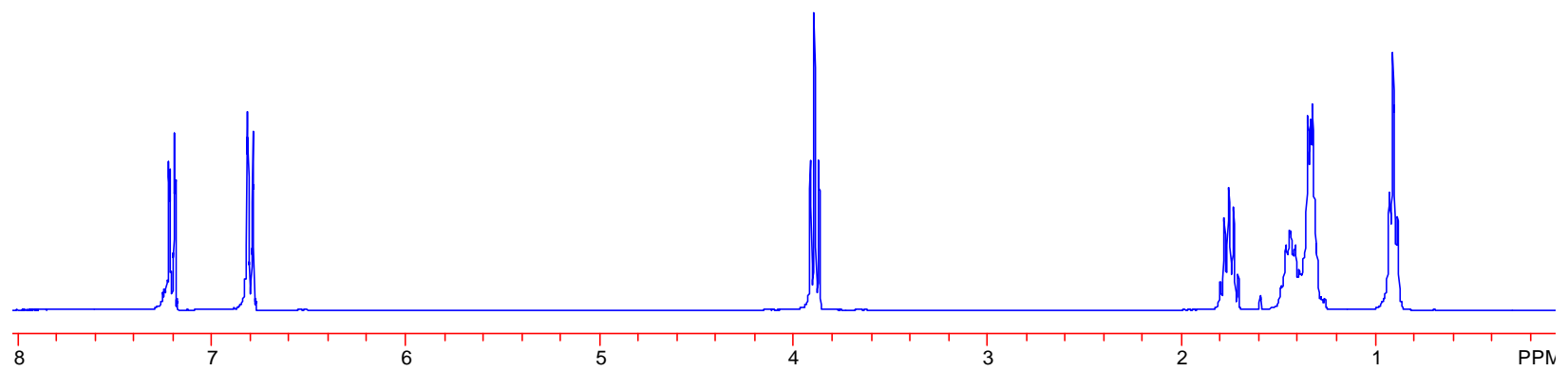

${ }^{13} \mathrm{C}\left\{{ }^{1} \mathrm{H}\right\}$ NMR $\left(\mathrm{CDCl}_{3}, 25^{\circ} \mathrm{C}\right)$ spectrum of 4-hexyloxychlorobenzene after removal of the volatiles and filtration through a short column $(1 \mathrm{x} 1 \mathrm{~cm})$ of silica (no chromatography: Method A-degassed).

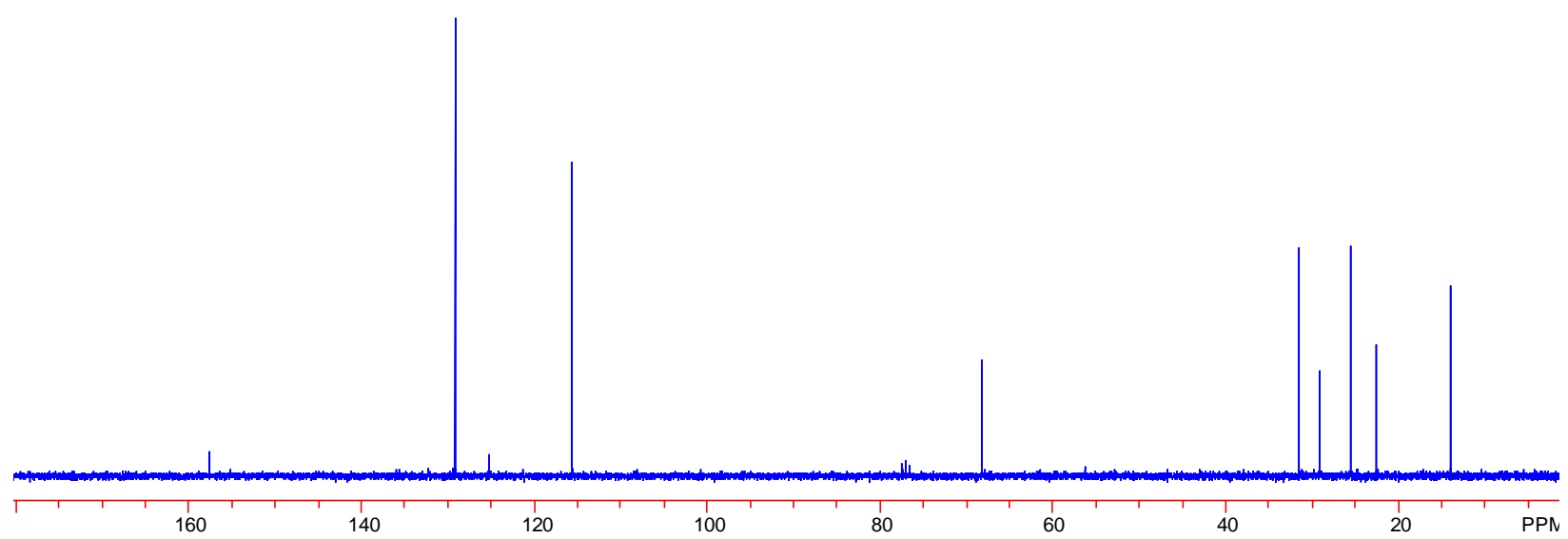


${ }^{1} \mathrm{H}$ NMR $\left(\mathrm{CDCl}_{3}, 25^{\circ} \mathrm{C}\right)$ spectrum of 4-propyloxychlorobenzene after removal

of the volatiles and filtration through a short column $(1 \times 1 \mathrm{~cm})$ of silica (no chromatography: Method A-degassed).

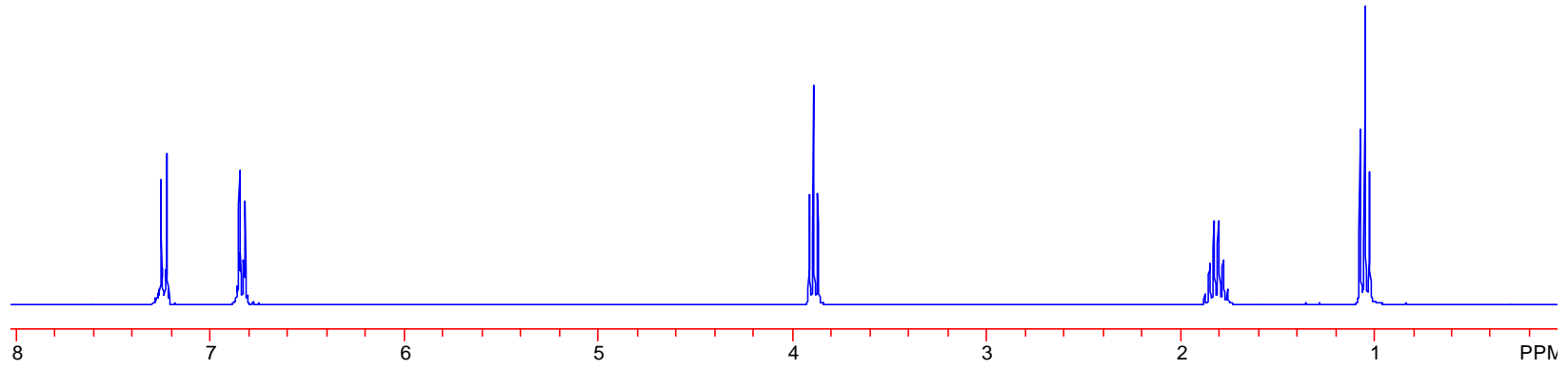

${ }^{13} \mathrm{C}\left\{{ }^{1} \mathrm{H}\right\}$ NMR $\left(\mathrm{CDCl}_{3}, 25{ }^{\circ} \mathrm{C}\right)$ spectrum of 4-propyloxychlorobenzene after removal of the volatiles and filtration through a short column $(1 \mathrm{x} 1 \mathrm{~cm})$ of silica (no chromatography: Method A-degassed).

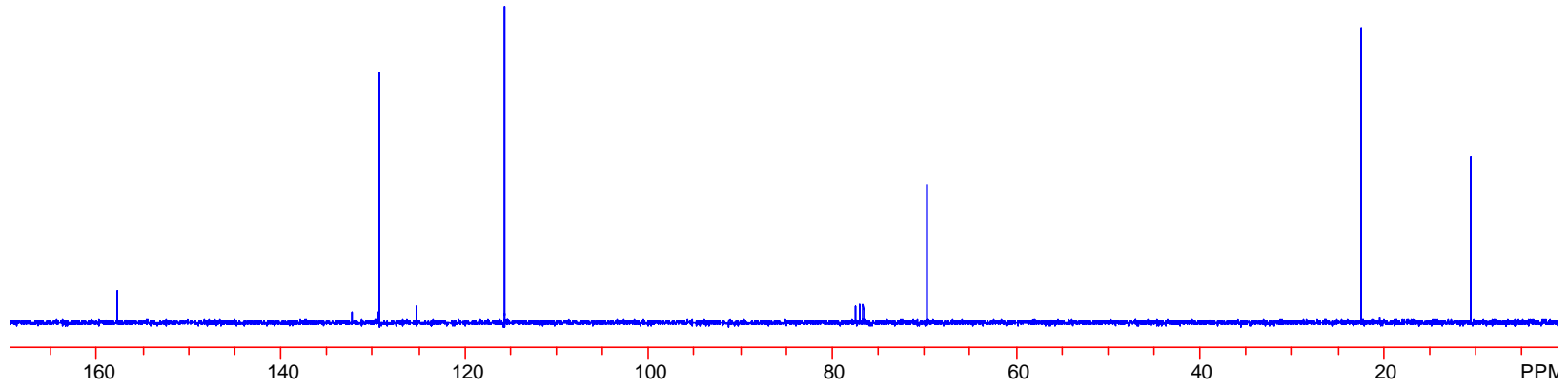




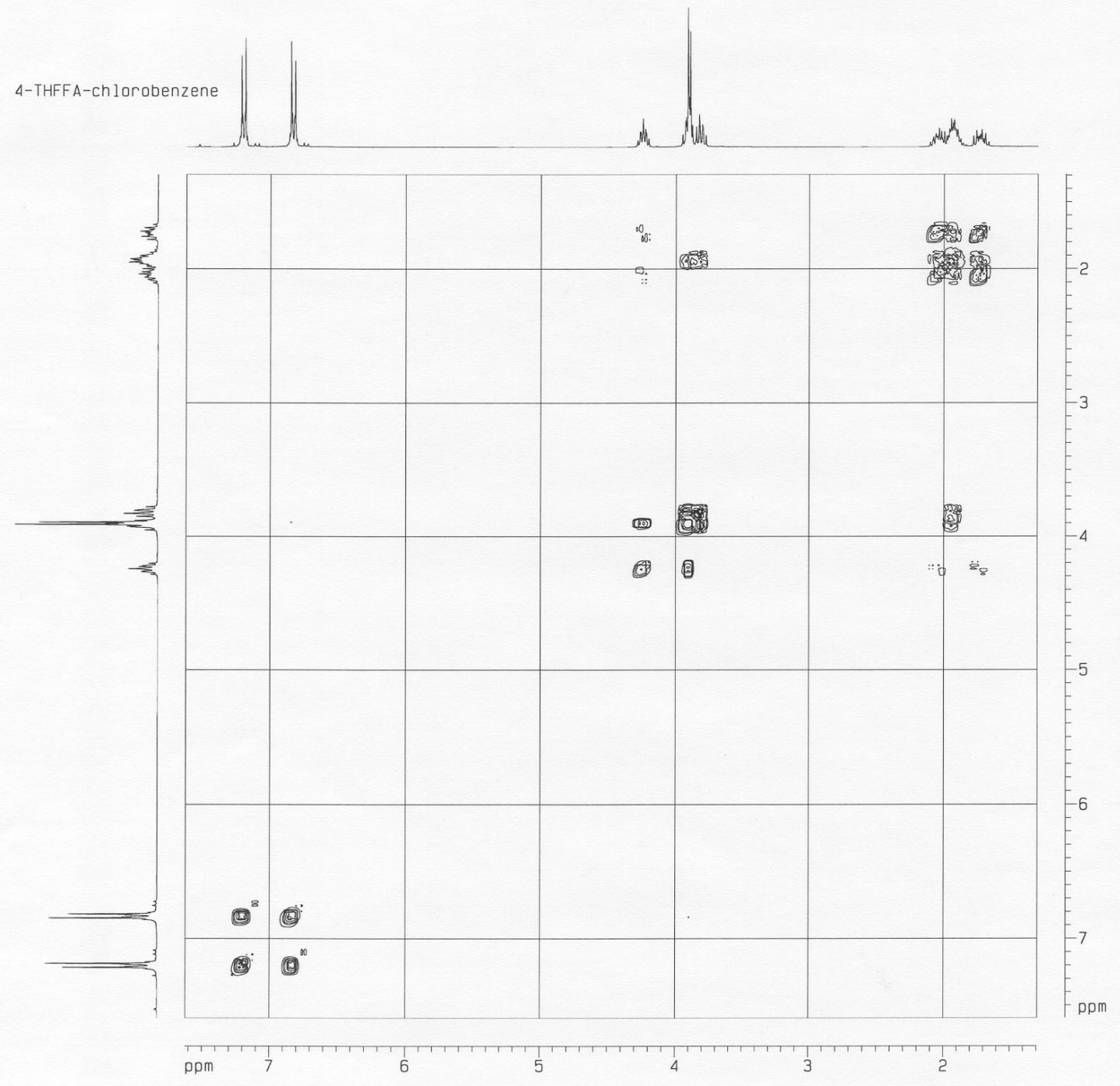

${ }^{1} \mathrm{H}-{ }^{1} \mathrm{H}$ COSY spectrum of 4-tetrahydrofurfurylchlorobenzene. 
CAS Numbers and citation information for the known compounds prepared in this study.

\section{4-tetrahydrofurfuryloxyaniline}

CAS \#: 91246-63-8

Alt, Gerhard H.; Wilder, Gene R., US 19600610, 1963. Chem. Abstr. 1963, 448296.

\section{4-ethyloxytoluene}

CAS \#: 622-60-6

Gesson J. P.; Digiusto L.; Jacquesy, J.C. Tetrahedron 1978, 34, 1715.

\section{4-propyloxytoluene}

CAS \#: 5349-18-8

Gesson J. P.; Digiusto L.; Jacquesy, J.C. Tetrahedron 1978, 34, 1715.

\section{4-hexyloxyanisole}

CAS \#:20743-91-3

Song, X. R.; Long, Y. K.; Li, D. Z.; Jia, D. Hubei Huagong 2002, 19, 16.

\section{4-propyloxyanisole}

CAS \#: 20743-94-6

Lee, E.; Lee, C.; Tae, J. S.; Wang, H. S.; Li, K. S. Tet. Lett. 1993, 34, 2343.

\section{2-propyloxytoluene}

CAS \#: 4607-37-8

Nafissi, M. M.; Koharski, D.P.; Puar, M. S.; Mcphail, A. T. J. Org. Chem. 1982, 47, 3345.

\section{2-hexyloxytoluene}

CAS \#: 57792-32-2

Bushby, R. J.; Cammidge, A. N.; Headdock, G.; Borner, R. C.; Boden, N. GB 2279072; WO 9429243, 1994. Chem. Abstr. 1995, 492091.

\section{butyloxybenzene}

CAS \#: 1126-79-0

Shintou, T.; Kikuchi, W.; Mukaiyama, T. Bull. Chem. Soc. Jpn. 2003, 76, 1645. 
propyloxybenzene

CAS \#: 622-85-5

Quach, T. D.; Batey, R. A. Org Lett. 2003, 5, 1381

\section{4-heptyloxyaniline}

CAS \#: 39905-44-7

Schmid, D. G.; Behnke, B.; Kempter, C.; Metzger, J. W.; Kuhn, R. Mikrochim. Acta 2001, 137, 111. 4-propyloxyaniline

CAS \#: 4469-80-1

Selva, M.; Tundo, P.; Perosa, A. J. Org. Chem. 2002, 67, 9238

\section{4-propyloxychlorobenzene}

CAS \#: 33382-58-0

Hirano M, Yakabe S, Monobe H, Morimoto T. Can. J. Chem. 1997, 75, 1905

\section{4-hexyloxychlorobenzene}

CAS \#: 6345-84-2

Hirano M, Yakabe S, Monobe H, Morimoto T. Can. J. Chem. 1997, 75, 1905. 


\section{Crystallographic Experimental Section}

\section{Data Collection}

A yellow crystal with approximate dimensions $0.49 \times 0.33 \times 0.28 \mathrm{~mm}^{3}$ was selected under oil under ambient conditions and attached to the tip of a nylon loop. The crystal was mounted in a stream of cold nitrogen at 100(2) K and centered in the X-ray beam by using a video camera.

The crystal evaluation and data collection were performed on a Bruker CCD-1000 diffractometer with Mo $\mathrm{K}_{\alpha}(\lambda=0.71073 \AA)$ radiation and the diffractometer to crystal distance of $4.9 \mathrm{~cm}$.

The initial cell constants were obtained from three series of $\omega$ scans at different starting angles. Each series consisted of 30 frames collected at intervals of $0.3^{\circ}$ in a $6^{\circ}$ range about $\omega$ with the exposure time of 10 seconds per frame. A total of 144 reflections was obtained. The reflections were successfully indexed by an automated indexing routine built in the SMART program. The final cell constants were calculated from a set of 6156 strong reflections from the actual data collection.

The data were collected by using the hemisphere data collection routine. The reciprocal space was surveyed to the extent of a full sphere to a resolution of $0.80 \AA$. A total of 8012 data were harvested by collecting three sets of frames with $0.25^{\circ}$ scans in $\omega$ with an exposure time 30 sec per frame. These highly redundant datasets were corrected for Lorentz and polarization effects. The absorption correction was based on fitting a function to the empirical transmission surface as sampled by multiple equivalent measurements. ${ }^{2}$

\section{Structure Solution and Refinement}

The systematic absences in the diffraction data were consistent for the space groups $R \overline{3}$ and $R 3$. The $E$-statistics strongly suggested the centrosymmetric space group $R \overline{3}$ that yielded chemically reasonable and computationally stable results of refinement [1].

A successful solution by the direct methods provided most non-hydrogen atoms from the $E$-map. The remaining non-hydrogen atoms were located in an alternating series of least-squares 
cycles and difference Fourier maps. All non-hydrogen atoms were refined with anisotropic displacement coefficients. All hydrogen atoms were included in the structure factor calculation at idealized positions and were allowed to ride on the neighboring atoms with relative isotropic displacement coefficients.

The heteroatomic cluster and the $\mathrm{PF}_{6}^{-}$counterion occupy crystallographic three-fold inversion axes. Atom $\mathrm{Cl}$ and $\mathrm{P}(2)$ reside on a crystallographic three-fold inversion axis. Atom $\mathrm{Cu}(2)$ resides on a crystallographic three-fold axis.

The final least-squares refinement of 91 parameters against 1588 data resulted in residuals $R$ (based on $F^{2}$ for $I \geq 2 \sigma$ ) and $w R$ (based on $F^{2}$ for all data) of 0.0218 and 0.0577 , respectively. The final difference Fourier map was featureless. 
Table 1. Crystal data and structure refinement for $\mathbf{1}$.

Identification code

sto009

Empirical formula

$\mathrm{C}_{12} \mathrm{H}_{36} \mathrm{Cl} \mathrm{Cu}_{8} \mathrm{~F}_{6} \mathrm{O}_{12} \mathrm{P}_{7} \mathrm{~S}_{12}$

Formula weight

Temperature

Wavelength

1631.69

100(2) K

$0.71073 \AA$

Crystal system

Rhombohedral

Space group

Unit cell dimensions

$R \overline{3}$

\begin{tabular}{|c|c|}
\hline$a=16.6111(4) \AA$ & $\alpha=90^{\circ}$. \\
\hline$b=16.6111(4) \AA$ & $\beta=90^{\circ}$. \\
\hline$c=14.6749(8) \AA$ & $\gamma=120^{\circ}$ \\
\hline
\end{tabular}

Volume

3506.7(2) $\AA^{3}$

Z

3

Density (calculated)

$2.318 \mathrm{Mg} / \mathrm{m}^{3}$

Absorption coefficient

$4.468 \mathrm{~mm}^{-1}$

$\mathrm{F}(000)$

2412

Crystal size

Theta range for data collection

$0.49 \times 0.33 \times 0.28 \mathrm{~mm}^{3}$

3.97 to $26.37^{\circ}$.

Index ranges

Reflections collected

$-20<=\mathrm{h}<=20,-20<=\mathrm{k}<=16,-18<=\mathrm{l}<=18$

Independent reflections

Completeness to theta $=26.37^{\circ}$

8012

$1588[\mathrm{R}($ int $)=0.0243]$

Absorption correction

Max. and min. transmission

Refinement method

Data / restraints / parameters

Goodness-of-fit on $\mathrm{F}^{2}$

$99.4 \%$

Multiscan with SADABS

0.3676 and 0.2181

Full-matrix least-squares on $\mathrm{F}^{2}$

1588 / 0 / 91

1.066

Final $R$ indices [I $>2 \operatorname{sigma}(\mathrm{I})]$

$\mathrm{R} 1=0.0218, \mathrm{wR} 2=0.0570$

$\mathrm{R}$ indices (all data)

$\mathrm{R} 1=0.0227, \mathrm{wR} 2=0.0577$

Largest diff. peak and hole

0.703 and -0.334 e. $\AA^{-3}$ 
Table 2. Atomic coordinates $\left(\mathrm{x} 10^{4}\right)$ and equivalent isotropic displacement parameters $\left(\AA^{2} \times 10^{3}\right)$ for $\mathbf{1}$. $U(\mathrm{eq})$ is defined as one third of the trace of the orthogonalized $\mathrm{U}^{\mathrm{ij}}$ tensor.

\begin{tabular}{lclcl}
\hline & $\mathrm{x}$ & $\mathrm{y}$ & $\mathrm{z}$ & $\mathrm{U}(\mathrm{eq})$ \\
\hline $\mathrm{Cu}(1)$ & $4124(1)$ & $5707(1)$ & $1041(1)$ & $16(1)$ \\
$\mathrm{Cu}(2)$ & 3333 & 6667 & $-157(1)$ & $18(1)$ \\
$\mathrm{Cl}$ & 3333 & 6667 & 1667 & $12(1)$ \\
$\mathrm{P}(1)$ & $1934(1)$ & $4239(1)$ & $97(1)$ & $13(1)$ \\
$\mathrm{P}(2)$ & 3333 & 6667 & -3333 & $19(1)$ \\
$\mathrm{S}(1)$ & $4618(1)$ & $6508(1)$ & $-291(1)$ & $15(1)$ \\
$\mathrm{S}(2)$ & $2790(1)$ & $4303(1)$ & $1112(1)$ & $14(1)$ \\
$\mathrm{F}(1)$ & $3039(1)$ & $5779(1)$ & $-2704(1)$ & $39(1)$ \\
$\mathrm{O}(1)$ & $2118(1)$ & $3785(1)$ & $-764(1)$ & $18(1)$ \\
$\mathrm{O}(2)$ & $900(1)$ & $3513(1)$ & $344(1)$ & $17(1)$ \\
$\mathrm{C}(1)$ & $3013(1)$ & $4232(1)$ & $-1228(1)$ & $21(1)$ \\
$\mathrm{C}(2)$ & $651(2)$ & $2604(1)$ & $720(2)$ & $29(1)$ \\
\hline
\end{tabular}


Table 3. Bond lengths $[\AA]$ and angles $\left[{ }^{\circ}\right]$ for $\mathbf{1}$.

\begin{tabular}{|c|c|c|c|}
\hline $\mathrm{Cu}(1)-\mathrm{S}(1)$ & $2.2737(5)$ & $P(1)-S(2)$ & $2.0250(6)$ \\
\hline $\mathrm{Cu}(1)-\mathrm{S}(2)$ & $2.2791(5)$ & $\mathrm{P}(2)-\mathrm{F}(1) \# 6$ & $1.5955(12)$ \\
\hline $\mathrm{Cu}(1)-\mathrm{S}(2) \# 1$ & $2.2856(5)$ & $\mathrm{P}(2)-\mathrm{F}(1) \# 3$ & $1.5956(12)$ \\
\hline $\mathrm{Cu}(1)-\mathrm{Cl}$ & $2.6840(2)$ & $\mathrm{P}(2)-\mathrm{F}(1) \# 7$ & $1.5956(12)$ \\
\hline $\mathrm{Cu}(2)-\mathrm{S}(1) \# 2$ & $2.2851(4)$ & $\mathrm{P}(2)-\mathrm{F}(1) \# 2$ & $1.5956(12)$ \\
\hline $\mathrm{Cu}(2)-\mathrm{S}(1) \# 3$ & $2.2851(4)$ & $\mathrm{P}(2)-\mathrm{F}(1)$ & $1.5956(12)$ \\
\hline $\mathrm{Cu}(2)-\mathrm{S}(1)$ & $2.2851(4)$ & $\mathrm{P}(2)-\mathrm{F}(1) \# 8$ & $1.5956(12)$ \\
\hline $\mathrm{Cu}(2)-\mathrm{Cl}$ & $2.6769(4)$ & $\mathrm{S}(1)-\mathrm{P}(1) \# 2$ & $2.0177(6)$ \\
\hline $\mathrm{Cl}-\mathrm{Cu}(2) \# 4$ & $2.6769(4)$ & $\mathrm{S}(2)-\mathrm{Cu}(1) \# 5$ & $2.2857(5)$ \\
\hline $\mathrm{Cl}-\mathrm{Cu}(1) \# 1$ & $2.6840(2)$ & $\mathrm{O}(1)-\mathrm{C}(1)$ & $1.458(2)$ \\
\hline $\mathrm{Cl}-\mathrm{Cu}(1) \# 5$ & $2.6840(2)$ & $\mathrm{O}(2)-\mathrm{C}(2)$ & $1.459(2)$ \\
\hline $\mathrm{Cl}-\mathrm{Cu}(1) \# 3$ & $2.6840(2)$ & $\mathrm{C}(1)-\mathrm{H}(1 \mathrm{~A})$ & 0.9800 \\
\hline $\mathrm{Cl}-\mathrm{Cu}(1) \# 2$ & $2.6840(2)$ & $\mathrm{C}(1)-\mathrm{H}(1 \mathrm{~B})$ & 0.9800 \\
\hline $\mathrm{Cl}-\mathrm{Cu}(1) \# 4$ & $2.6841(2)$ & $\mathrm{C}(1)-\mathrm{H}(1 \mathrm{C})$ & 0.9800 \\
\hline $\mathrm{P}(1)-\mathrm{O}(2)$ & $1.5696(13)$ & $\mathrm{C}(2)-\mathrm{H}(2 \mathrm{~A})$ & 0.9800 \\
\hline $\mathrm{P}(1)-\mathrm{O}(1)$ & $1.5773(13)$ & $\mathrm{C}(2)-\mathrm{H}(2 \mathrm{~B})$ & 0.9800 \\
\hline $\mathrm{P}(1)-\mathrm{S}(1) \# 3$ & $2.0177(6)$ & $\mathrm{C}(2)-\mathrm{H}(2 \mathrm{C})$ & 0.9800 \\
\hline $\mathrm{S}(1)-\mathrm{Cu}(1)-\mathrm{S}(2)$ & $121.319(18)$ & $\mathrm{Cu}(1) \# 5-\mathrm{Cl}-\mathrm{Cu}(1) \# 4$ & $108.922(5)$ \\
\hline $\mathrm{S}(1)-\mathrm{Cu}(1)-\mathrm{S}(2) \# 1$ & $118.575(18)$ & $\mathrm{Cu}(1) \# 3-\mathrm{Cl}-\mathrm{Cu}(1) \# 4$ & $71.076(5)$ \\
\hline $\mathrm{S}(2)-\mathrm{Cu}(1)-\mathrm{S}(2) \# 1$ & $118.204(12)$ & $\mathrm{Cu}(1) \# 2-\mathrm{Cl}-\mathrm{Cu}(1) \# 4$ & $71.076(5)$ \\
\hline $\mathrm{S}(1)-\mathrm{Cu}(1)-\mathrm{Cl}$ & $94.985(13)$ & $\mathrm{Cu}(1)-\mathrm{Cl}-\mathrm{Cu}(1) \# 4$ & 180.0 \\
\hline $\mathrm{S}(2)-\mathrm{Cu}(1)-\mathrm{Cl}$ & $94.467(13)$ & $\mathrm{O}(2)-\mathrm{P}(1)-\mathrm{O}(1)$ & $102.52(7)$ \\
\hline $\mathrm{S}(2) \# 1-\mathrm{Cu}(1)-\mathrm{Cl}$ & $94.312(13)$ & $\mathrm{O}(2)-\mathrm{P}(1)-\mathrm{S}(1) \# 3$ & $104.36(5)$ \\
\hline $\mathrm{S}(1) \# 2-\mathrm{Cu}(2)-\mathrm{S}(1) \# 3$ & $119.276(4)$ & $\mathrm{O}(1)-\mathrm{P}(1)-\mathrm{S}(1) \# 3$ & $109.32(5)$ \\
\hline $\mathrm{S}(1) \# 2-\mathrm{Cu}(2)-\mathrm{S}(1)$ & $119.276(4)$ & $\mathrm{O}(2)-\mathrm{P}(1)-\mathrm{S}(2)$ & $109.89(5)$ \\
\hline $\mathrm{S}(1) \# 3-\mathrm{Cu}(2)-\mathrm{S}(1)$ & $119.276(4)$ & $\mathrm{O}(1)-\mathrm{P}(1)-\mathrm{S}(2)$ & $108.38(5)$ \\
\hline $\mathrm{S}(1) \# 2-\mathrm{Cu}(2)-\mathrm{Cl}$ & $94.909(15)$ & $\mathrm{S}(1) \# 3-\mathrm{P}(1)-\mathrm{S}(2)$ & $120.83(3)$ \\
\hline $\mathrm{S}(1) \# 3-\mathrm{Cu}(2)-\mathrm{Cl}$ & $94.909(15)$ & $\mathrm{F}(1) \# 6-\mathrm{P}(2)-\mathrm{F}(1) \# 3$ & $180.00(8)$ \\
\hline $\mathrm{S}(1)-\mathrm{Cu}(2)-\mathrm{Cl}$ & $94.909(15)$ & $\mathrm{F}(1) \# 6-\mathrm{P}(2)-\mathrm{F}(1) \# 7$ & $89.83(7)$ \\
\hline $\mathrm{Cu}(2)-\mathrm{Cl}-\mathrm{Cu}(2) \# 4$ & 180.0 & $\mathrm{~F}(1) \# 3-\mathrm{P}(2)-\mathrm{F}(1) \# 7$ & $90.17(7)$ \\
\hline $\mathrm{Cu}(2)-\mathrm{Cl}-\mathrm{Cu}(1) \# 1$ & $110.014(4)$ & $\mathrm{F}(1) \# 6-\mathrm{P}(2)-\mathrm{F}(1) \# 2$ & $90.17(7)$ \\
\hline $\mathrm{Cu}(2) \# 4-\mathrm{Cl}-\mathrm{Cu}(1) \# 1$ & $69.986(4)$ & $\mathrm{F}(1) \# 3-\mathrm{P}(2)-\mathrm{F}(1) \# 2$ & $89.83(7)$ \\
\hline $\mathrm{Cu}(2)-\mathrm{Cl}-\mathrm{Cu}(1) \# 5$ & $110.014(4)$ & $\mathrm{F}(1) \# 7-\mathrm{P}(2)-\mathrm{F}(1) \# 2$ & 180.0 \\
\hline $\mathrm{Cu}(2) \# 4-\mathrm{Cl}-\mathrm{Cu}(1) \# 5$ & $69.986(4)$ & $\mathrm{F}(1) \# 6-\mathrm{P}(2)-\mathrm{F}(1)$ & $90.17(7)$ \\
\hline $\mathrm{Cu}(1) \# 1-\mathrm{Cl}-\mathrm{Cu}(1) \# 5$ & $108.925(4)$ & $\mathrm{F}(1) \# 3-\mathrm{P}(2)-\mathrm{F}(1)$ & $89.83(7)$ \\
\hline $\mathrm{Cu}(2)-\mathrm{Cl}-\mathrm{Cu}(1) \# 3$ & $69.987(4)$ & $\mathrm{F}(1) \# 7-\mathrm{P}(2)-\mathrm{F}(1)$ & $90.17(7)$ \\
\hline $\mathrm{Cu}(2) \# 4-\mathrm{Cl}-\mathrm{Cu}(1) \# 3$ & $110.012(4)$ & $\mathrm{F}(1) \# 2-\mathrm{P}(2)-\mathrm{F}(1)$ & $89.83(7)$ \\
\hline $\mathrm{Cu}(1) \# 1-\mathrm{Cl}-\mathrm{Cu}(1) \# 3$ & 180.0 & $\mathrm{~F}(1) \# 6-\mathrm{P}(2)-\mathrm{F}(1) \# 8$ & $89.83(7)$ \\
\hline $\mathrm{Cu}(1) \# 5-\mathrm{Cl}-\mathrm{Cu}(1) \# 3$ & $71.076(4)$ & $\mathrm{F}(1) \# 3-\mathrm{P}(2)-\mathrm{F}(1) \# 8$ & $90.17(7)$ \\
\hline $\mathrm{Cu}(2)-\mathrm{Cl}-\mathrm{Cu}(1) \# 2$ & $69.987(4)$ & $\mathrm{F}(1) \# 7-\mathrm{P}(2)-\mathrm{F}(1) \# 8$ & $89.83(7)$ \\
\hline $\mathrm{Cu}(2) \# 4-\mathrm{Cl}-\mathrm{Cu}(1) \# 2$ & $110.013(4)$ & $\mathrm{F}(1) \# 2-\mathrm{P}(2)-\mathrm{F}(1) \# 8$ & $90.17(7)$ \\
\hline $\mathrm{Cu}(1) \# 1-\mathrm{Cl}-\mathrm{Cu}(1) \# 2$ & $71.076(5)$ & $\mathrm{F}(1)-\mathrm{P}(2)-\mathrm{F}(1) \# 8$ & 180.0 \\
\hline $\mathrm{Cu}(1) \# 5-\mathrm{Cl}-\mathrm{Cu}(1) \# 2$ & 180.0 & $\mathrm{P}(1) \# 2-\mathrm{S}(1)-\mathrm{Cu}(1)$ & $102.56(2)$ \\
\hline $\mathrm{Cu}(1) \# 3-\mathrm{Cl}-\mathrm{Cu}(1) \# 2$ & $108.924(4)$ & $\mathrm{P}(1) \# 2-\mathrm{S}(1)-\mathrm{Cu}(2)$ & $109.90(2)$ \\
\hline $\mathrm{Cu}(2)-\mathrm{Cl}-\mathrm{Cu}(1)$ & $69.987(4)$ & $\mathrm{Cu}(1)-\mathrm{S}(1)-\mathrm{Cu}(2)$ & $84.813(17)$ \\
\hline $\mathrm{Cu}(2) \# 4-\mathrm{Cl}-\mathrm{Cu}(1)$ & $110.015(4)$ & $\mathrm{P}(1)-\mathrm{S}(2)-\mathrm{Cu}(1)$ & $108.56(2)$ \\
\hline $\mathrm{Cu}(1) \# 1-\mathrm{Cl}-\mathrm{Cu}(1)$ & 71.078(4) & $\mathrm{P}(1)-\mathrm{S}(2)-\mathrm{Cu}(1) \# 5$ & $102.71(2)$ \\
\hline $\mathrm{Cu}(1) \# 5-\mathrm{Cl}-\mathrm{Cu}(1)$ & $71.078(5)$ & $\mathrm{Cu}(1)-\mathrm{S}(2)-\mathrm{Cu}(1) \# 5$ & $86.242(18)$ \\
\hline $\mathrm{Cu}(1) \# 3-\mathrm{Cl}-\mathrm{Cu}(1)$ & $108.924(5)$ & $\mathrm{C}(1)-\mathrm{O}(1)-\mathrm{P}(1)$ & $121.57(11)$ \\
\hline $\mathrm{Cu}(1) \# 2-\mathrm{Cl}-\mathrm{Cu}(1)$ & $108.924(5)$ & $\mathrm{C}(2)-\mathrm{O}(2)-\mathrm{P}(1)$ & 121.17(12) \\
\hline $\mathrm{Cu}(2)-\mathrm{Cl}-\mathrm{Cu}(1) \# 4$ & $110.014(4)$ & $\mathrm{O}(1)-\mathrm{C}(1)-\mathrm{H}(1 \mathrm{~A})$ & 109.5 \\
\hline $\mathrm{Cu}(2) \# 4-\mathrm{Cl}-\mathrm{Cu}(1) \# 4$ & $69.985(4)$ & $\mathrm{O}(1)-\mathrm{C}(1)-\mathrm{H}(1 \mathrm{~B})$ & 109.5 \\
\hline $\mathrm{Cu}(1) \# 1-\mathrm{Cl}-\mathrm{Cu}(1) \# 4$ & $108.922(4)$ & $\mathrm{H}(1 \mathrm{~A})-\mathrm{C}(1)-\mathrm{H}(1 \mathrm{~B})$ & 109.5 \\
\hline
\end{tabular}


$\mathrm{O}(1)-\mathrm{C}(1)-\mathrm{H}(1 \mathrm{C})$

$\mathrm{H}(1 \mathrm{~A})-\mathrm{C}(1)-\mathrm{H}(1 \mathrm{C})$

$\mathrm{H}(1 \mathrm{~B})-\mathrm{C}(1)-\mathrm{H}(1 \mathrm{C})$

$\mathrm{O}(2)-\mathrm{C}(2)-\mathrm{H}(2 \mathrm{~A})$

$\mathrm{O}(2)-\mathrm{C}(2)-\mathrm{H}(2 \mathrm{~B})$
109.5

109.5

109.5

109.5

109.5
$\mathrm{H}(2 \mathrm{~A})-\mathrm{C}(2)-\mathrm{H}(2 \mathrm{~B})$

$\mathrm{O}(2)-\mathrm{C}(2)-\mathrm{H}(2 \mathrm{C})$

$\mathrm{H}(2 \mathrm{~A})-\mathrm{C}(2)-\mathrm{H}(2 \mathrm{C})$

$\mathrm{H}(2 \mathrm{~B})-\mathrm{C}(2)-\mathrm{H}(2 \mathrm{C})$
109.5

109.5

109.5

109.5

Symmetry transformations used to generate equivalent atoms:

\#1 $\mathrm{x}-\mathrm{y}+2 / 3, \mathrm{x}+1 / 3,-\mathrm{z}+1 / 3 \quad \# 2-\mathrm{y}+1, \mathrm{x}-\mathrm{y}+1, \mathrm{z} \quad \# 3-\mathrm{x}+\mathrm{y},-\mathrm{x}+1, \mathrm{z}$

$\# 4-x+2 / 3,-y+4 / 3,-z+1 / 3 \quad \# 5 y-1 / 3,-x+y+1 / 3,-z+1 / 3$

\#6 $\mathrm{x}-\mathrm{y}+2 / 3, \mathrm{x}+1 / 3,-\mathrm{z}-2 / 3 \quad \# 7 \mathrm{y}-1 / 3,-\mathrm{x}+\mathrm{y}+1 / 3,-\mathrm{z}-2 / 3$

$\# 8-x+2 / 3,-y+4 / 3,-z-2 / 3$ 
Table 4. Anisotropic displacement parameters $\left(\AA^{2} \times 10^{3}\right)$ for 1 . The anisotropic displacement factor exponent takes the form: $-2 \pi^{2}\left[h^{2} a^{* 2} U^{11}+\ldots+2 h k a^{*} b^{*} U^{12}\right]$

\begin{tabular}{lcccccc}
\hline & $\mathrm{U}^{11}$ & $\mathrm{U}^{22}$ & $\mathrm{U}^{33}$ & $\mathrm{U}^{23}$ & $\mathrm{U}^{13}$ & $\mathrm{U}^{12}$ \\
\hline $\mathrm{Cu}(1)$ & $14(1)$ & $15(1)$ & $17(1)$ & $1(1)$ & $0(1)$ & $6(1)$ \\
$\mathrm{Cu}(2)$ & $15(1)$ & $15(1)$ & $23(1)$ & 0 & 0 & $7(1)$ \\
$\mathrm{Cl}$ & $11(1)$ & $11(1)$ & $14(1)$ & 0 & 0 & $6(1)$ \\
$\mathrm{P}(1)$ & $12(1)$ & $11(1)$ & $15(1)$ & $-2(1)$ & $-1(1)$ & $5(1)$ \\
$\mathrm{P}(2)$ & $16(1)$ & $16(1)$ & $24(1)$ & 0 & 0 & $8(1)$ \\
$\mathrm{S}(1)$ & $14(1)$ & $14(1)$ & $15(1)$ & $-1(1)$ & $1(1)$ & $6(1)$ \\
$\mathrm{S}(2)$ & $13(1)$ & $12(1)$ & $17(1)$ & $0(1)$ & $-1(1)$ & $7(1)$ \\
$\mathrm{F}(1)$ & $51(1)$ & $27(1)$ & $39(1)$ & $11(1)$ & $3(1)$ & $18(1)$ \\
$\mathrm{O}(1)$ & $16(1)$ & $17(1)$ & $19(1)$ & $-5(1)$ & $0(1)$ & $8(1)$ \\
$\mathrm{O}(2)$ & $12(1)$ & $13(1)$ & $24(1)$ & $0(1)$ & $0(1)$ & $5(1)$ \\
$\mathrm{C}(1)$ & $19(1)$ & $24(1)$ & $20(1)$ & $-2(1)$ & $3(1)$ & $10(1)$ \\
$\mathrm{C}(2)$ & $21(1)$ & $14(1)$ & $49(1)$ & $8(1)$ & $5(1)$ & $6(1)$ \\
& & & & & & \\
\hline
\end{tabular}


Table 5. Hydrogen coordinates ( $\left.\mathrm{x} 10^{4}\right)$ and isotropic displacement parameters $\left(\AA^{2} \times 10^{3}\right)$ for 1 .

\begin{tabular}{lrrrr}
\hline & $x$ & $y$ & $z$ & $U(e q)$ \\
\hline$H(1 A)$ & 3159 & 4850 & -1437 & 32 \\
$H(1 B)$ & 2986 & 3854 & -1754 & 32 \\
$H(1 C)$ & 3497 & 4290 & -807 & 32 \\
$H(2 A)$ & 921 & 2313 & 342 & 43 \\
$H(2 B)$ & -28 & 2210 & 728 & 43 \\
H(2C) & 891 & 2680 & 1342 & 43 \\
\hline
\end{tabular}


Table 6. Torsion angles $\left[{ }^{\circ}\right]$ for $\mathbf{1}$.

\begin{tabular}{|c|c|c|c|}
\hline 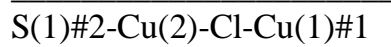 & $-87.438(12)$ & $\mathrm{O}(2)-\mathrm{P}(1)-\mathrm{S}(2)-\mathrm{Cu}(1) \# 5$ & $-66.48(6)$ \\
\hline $\mathrm{S}(1) \# 3-\mathrm{Cu}(2)-\mathrm{Cl}-\mathrm{Cu}(1) \# 1$ & $152.562(12)$ & $\mathrm{O}(1)-\mathrm{P}(1)-\mathrm{S}(2)-\mathrm{Cu}(1) \# 5$ & $-177.77(5)$ \\
\hline $\mathrm{S}(1)-\mathrm{Cu}(2)-\mathrm{Cl}-\mathrm{Cu}(1) \# 1$ & $32.562(12)$ & $\mathrm{S}(1) \# 3-\mathrm{P}(1)-\mathrm{S}(2)-\mathrm{Cu}(1) \# 5$ & $55.06(3)$ \\
\hline $\mathrm{S}(1) \# 2-\mathrm{Cu}(2)-\mathrm{Cl}-\mathrm{Cu}(1) \# 5$ & $152.559(12)$ & $\mathrm{S}(1)-\mathrm{Cu}(1)-\mathrm{S}(2)-\mathrm{P}(1)$ & $-25.92(3)$ \\
\hline $\mathrm{S}(1) \# 3-\mathrm{Cu}(2)-\mathrm{Cl}-\mathrm{Cu}(1) \# 5$ & $32.559(12)$ & $\mathrm{S}(2) \# 1-\mathrm{Cu}(1)-\mathrm{S}(2)-\mathrm{P}(1)$ & $170.00(2)$ \\
\hline $\mathrm{S}(1)-\mathrm{Cu}(2)-\mathrm{Cl}-\mathrm{Cu}(1) \# 5$ & $-87.441(12)$ & $\mathrm{Cl}-\mathrm{Cu}(1)-\mathrm{S}(2)-\mathrm{P}(1)$ & $72.68(2)$ \\
\hline $\mathrm{S}(1) \# 2-\mathrm{Cu}(2)-\mathrm{Cl}-\mathrm{Cu}(1) \# 3$ & $92.560(12)$ & $\mathrm{S}(1)-\mathrm{Cu}(1)-\mathrm{S}(2)-\mathrm{Cu}(1) \# 5$ & $-128.079(17)$ \\
\hline $\mathrm{S}(1) \# 3-\mathrm{Cu}(2)-\mathrm{Cl}-\mathrm{Cu}(1) \# 3$ & $-27.440(12)$ & $\mathrm{S}(2) \# 1-\mathrm{Cu}(1)-\mathrm{S}(2)-\mathrm{Cu}(1) \# 5$ & $67.85(3)$ \\
\hline $\mathrm{S}(1)-\mathrm{Cu}(2)-\mathrm{Cl}-\mathrm{Cu}(1) \# 3$ & $-147.440(12)$ & $\mathrm{Cl}-\mathrm{Cu}(1)-\mathrm{S}(2)-\mathrm{Cu}(1) \# 5$ & $-29.477(12)$ \\
\hline $\mathrm{S}(1) \# 2-\mathrm{Cu}(2)-\mathrm{Cl}-\mathrm{Cu}(1) \# 2$ & $-27.440(12)$ & $\mathrm{O}(2)-\mathrm{P}(1)-\mathrm{O}(1)-\mathrm{C}(1)$ & $-179.78(13)$ \\
\hline $\mathrm{S}(1) \# 3-\mathrm{Cu}(2)-\mathrm{Cl}-\mathrm{Cu}(1) \# 2$ & $-147.439(12)$ & $\mathrm{S}(1) \# 3-\mathrm{P}(1)-\mathrm{O}(1)-\mathrm{C}(1)$ & $69.92(14)$ \\
\hline $\mathrm{S}(1)-\mathrm{Cu}(2)-\mathrm{Cl}-\mathrm{Cu}(1) \# 2$ & $92.560(12)$ & $\mathrm{S}(2)-\mathrm{P}(1)-\mathrm{O}(1)-\mathrm{C}(1)$ & $-63.61(14)$ \\
\hline $\mathrm{S}(1) \# 2-\mathrm{Cu}(2)-\mathrm{Cl}-\mathrm{Cu}(1)$ & $-147.440(12)$ & $\mathrm{O}(1)-\mathrm{P}(1)-\mathrm{O}(2)-\mathrm{C}(2)$ & $70.33(15)$ \\
\hline $\mathrm{S}(1) \# 3-\mathrm{Cu}(2)-\mathrm{Cl}-\mathrm{Cu}(1)$ & $92.560(12)$ & $\mathrm{S}(1) \# 3-\mathrm{P}(1)-\mathrm{O}(2)-\mathrm{C}(2)$ & $-175.68(14)$ \\
\hline $\mathrm{S}(1)-\mathrm{Cu}(2)-\mathrm{Cl}-\mathrm{Cu}(1)$ & $-27.440(12)$ & $\mathrm{S}(2)-\mathrm{P}(1)-\mathrm{O}(2)-\mathrm{C}(2)$ & $-44.75(15)$ \\
\hline $\mathrm{S}(1) \# 2-\mathrm{Cu}(2)-\mathrm{Cl}-\mathrm{Cu}(1) \# 4$ & $32.561(12)$ & & \\
\hline $\mathrm{S}(1) \# 3-\mathrm{Cu}(2)-\mathrm{Cl}-\mathrm{Cu}(1) \# 4$ & $-87.439(12)$ & & \\
\hline $\mathrm{S}(1)-\mathrm{Cu}(2)-\mathrm{Cl}-\mathrm{Cu}(1) \# 4$ & $152.561(12)$ & & \\
\hline $\mathrm{S}(1)-\mathrm{Cu}(1)-\mathrm{Cl}-\mathrm{Cu}(2)$ & $27.593(12)$ & & \\
\hline $\mathrm{S}(2)-\mathrm{Cu}(1)-\mathrm{Cl}-\mathrm{Cu}(2)$ & $-94.424(12)$ & & \\
\hline $\mathrm{S}(2) \# 1-\mathrm{Cu}(1)-\mathrm{Cl}-\mathrm{Cu}(2)$ & 146.806(13) & & \\
\hline $\mathrm{S}(1)-\mathrm{Cu}(1)-\mathrm{Cl}-\mathrm{Cu}(2) \# 4$ & $-152.407(12)$ & & \\
\hline $\mathrm{S}(2)-\mathrm{Cu}(1)-\mathrm{Cl}-\mathrm{Cu}(2) \# 4$ & $85.575(12)$ & & \\
\hline $\mathrm{S}(2) \# 1-\mathrm{Cu}(1)-\mathrm{Cl}-\mathrm{Cu}(2) \# 4$ & $-33.194(13)$ & & \\
\hline $\mathrm{S}(1)-\mathrm{Cu}(1)-\mathrm{Cl}-\mathrm{Cu}(1) \# 1$ & $-93.066(12)$ & & \\
\hline $\mathrm{S}(2)-\mathrm{Cu}(1)-\mathrm{Cl}-\mathrm{Cu}(1) \# 1$ & $144.917(16)$ & & \\
\hline $\mathrm{S}(2) \# 1-\mathrm{Cu}(1)-\mathrm{Cl}-\mathrm{Cu}(1) \# 1$ & $26.147(13)$ & & \\
\hline $\mathrm{S}(1)-\mathrm{Cu}(1)-\mathrm{Cl}-\mathrm{Cu}(1) \# 5$ & $148.252(14)$ & & \\
\hline $\mathrm{S}(2)-\mathrm{Cu}(1)-\mathrm{Cl}-\mathrm{Cu}(1) \# 5$ & $26.234(11)$ & & \\
\hline $\mathrm{S}(2) \# 1-\mathrm{Cu}(1)-\mathrm{Cl}-\mathrm{Cu}(1) \# 5$ & $-92.535(15)$ & & \\
\hline $\mathrm{S}(1)-\mathrm{Cu}(1)-\mathrm{Cl}-\mathrm{Cu}(1) \# 3$ & $86.935(12)$ & & \\
\hline $\mathrm{S}(2)-\mathrm{Cu}(1)-\mathrm{Cl}-\mathrm{Cu}(1) \# 3$ & $-35.083(16)$ & & \\
\hline $\mathrm{S}(2) \# 1-\mathrm{Cu}(1)-\mathrm{Cl}-\mathrm{Cu}(1) \# 3$ & $-153.852(13)$ & & \\
\hline $\mathrm{S}(1)-\mathrm{Cu}(1)-\mathrm{Cl}-\mathrm{Cu}(1) \# 2$ & $-31.749(14)$ & & \\
\hline $\mathrm{S}(2)-\mathrm{Cu}(1)-\mathrm{Cl}-\mathrm{Cu}(1) \# 2$ & $-153.766(11)$ & & \\
\hline $\mathrm{S}(2) \# 1-\mathrm{Cu}(1)-\mathrm{Cl}-\mathrm{Cu}(1) \# 2$ & $87.465(15)$ & & \\
\hline $\mathrm{S}(1)-\mathrm{Cu}(1)-\mathrm{Cl}-\mathrm{Cu}(1) \# 4$ & $177(100)$ & & \\
\hline $\mathrm{S}(2)-\mathrm{Cu}(1)-\mathrm{Cl}-\mathrm{Cu}(1) \# 4$ & $55(54)$ & & \\
\hline $\mathrm{S}(2) \# 1-\mathrm{Cu}(1)-\mathrm{Cl}-\mathrm{Cu}(1) \# 4$ & $-63(54)$ & & \\
\hline $\mathrm{S}(2)-\mathrm{Cu}(1)-\mathrm{S}(1)-\mathrm{P}(1) \# 2$ & $176.78(2)$ & & \\
\hline $\mathrm{S}(2) \# 1-\mathrm{Cu}(1)-\mathrm{S}(1)-\mathrm{P}(1) \# 2$ & $-19.20(3)$ & & \\
\hline $\mathrm{Cl}-\mathrm{Cu}(1)-\mathrm{S}(1)-\mathrm{P}(1) \# 2$ & $78.47(2)$ & & \\
\hline $\mathrm{S}(2)-\mathrm{Cu}(1)-\mathrm{S}(1)-\mathrm{Cu}(2)$ & $67.52(2)$ & & \\
\hline $\mathrm{S}(2) \# 1-\mathrm{Cu}(1)-\mathrm{S}(1)-\mathrm{Cu}(2)$ & $-128.461(18)$ & & \\
\hline $\mathrm{Cl}-\mathrm{Cu}(1)-\mathrm{S}(1)-\mathrm{Cu}(2)$ & $-30.792(13)$ & & \\
\hline $\mathrm{S}(1) \# 2-\mathrm{Cu}(2)-\mathrm{S}(1)-\mathrm{P}(1) \# 2$ & 27.81(4) & & \\
\hline $\mathrm{S}(1) \# 3-\mathrm{Cu}(2)-\mathrm{S}(1)-\mathrm{P}(1) \# 2$ & $-169.05(2)$ & & \\
\hline $\mathrm{Cl}-\mathrm{Cu}(2)-\mathrm{S}(1)-\mathrm{P}(1) \# 2$ & $-70.62(2)$ & & \\
\hline $\mathrm{S}(1) \# 2-\mathrm{Cu}(2)-\mathrm{S}(1)-\mathrm{Cu}(1)$ & $129.31(2)$ & & \\
\hline $\mathrm{S}(1) \# 3-\mathrm{Cu}(2)-\mathrm{S}(1)-\mathrm{Cu}(1)$ & $-67.55(3)$ & & \\
\hline $\mathrm{Cl}-\mathrm{Cu}(2)-\mathrm{S}(1)-\mathrm{Cu}(1)$ & $30.880(12)$ & & \\
\hline $\mathrm{O}(2)-\mathrm{P}(1)-\mathrm{S}(2)-\mathrm{Cu}(1)$ & $-156.76(5)$ & & \\
\hline $\mathrm{O}(1)-\mathrm{P}(1)-\mathrm{S}(2)-\mathrm{Cu}(1)$ & $91.95(6)$ & & \\
\hline $\mathrm{S}(1) \# 3-\mathrm{P}(1)-\mathrm{S}(2)-\mathrm{Cu}(1)$ & $-35.22(4)$ & & \\
\hline
\end{tabular}


Symmetry transformations used to generate equivalent atoms:

$\# 1 \mathrm{x}-\mathrm{y}+2 / 3, \mathrm{x}+1 / 3,-\mathrm{z}+1 / 3 \quad \# 2-\mathrm{y}+1, \mathrm{x}-\mathrm{y}+1, \mathrm{z} \quad \# 3-\mathrm{x}+\mathrm{y},-\mathrm{x}+1, \mathrm{z}$

$\# 4-x+2 / 3,-y+4 / 3,-z+1 / 3 \quad \# 5 y-1 / 3,-x+y+1 / 3,-z+1 / 3$

$\# 6 x-y+2 / 3, x+1 / 3,-z-2 / 3 \quad \# 7 y-1 / 3,-x+y+1 / 3,-z-2 / 3$

$\# 8-x+2 / 3,-y+4 / 3,-z-2 / 3$

${ }^{1}$ Chen, H. W.; Paparizos, C.; Fackler, J. P. Jr. Inorg. Chim. Acta. 1985, 96, 137.

${ }^{2}$ Bruker-AXS. (2000-2003) SADABS V.2.05, SAINT V.6.22, SHELXTL V.6.10

\& SMART 5.622 Software Reference Manuals. Bruker-AXS, Madison, Wisconsin, USA. 